\title{
PRIVATE LENDERS, BANKS AND MORTGAGE CREDIT IN PERU. EVIDENCE FROM NOTARISED LOANS*
}

LUIS FELIPE ZEGARRA

CENTRUM Católica Graduate Business School ${ }^{\mathrm{a}}$

\begin{abstract}
This article examines the mortgage credit market of Peru during the guano era and analyses the effects of the creation of mortgage banks on the allocation of credit. It shows that mortgage banks served as interregional intermediaries and facilitated access to long-term credit for large estate owners. However, banks did not broaden access to credit. As private lenders, mortgage banks loaned largely to Lima's merchants and renters and to hacendados from the main coastal valleys.
\end{abstract}

Keywords: banks, mortgage credit, Latin America, Peru

JEL Code: G21, N26

* Received 30 July 2015. Accepted 28 March 2016. The author thank the two anonymous referees for their comments and suggestions, as well as Franco Lobo and María Flores, who assisted the author in the process of data collection.

a Department of Economics and Finance, CENTRUM Católica Graduate Business School, Pontificia Universidad Católica del Perú (PUCP), Jr. Daniel Alomía Robles 125, Los Alamos de Monterrico, Santiago de Surco, Lima, Perú. lfzegarrab@pucp.pe 


\section{RESUMEN}

Este artículo examina el mercado de crédito hipotecario del Perú durante la era del guano y analiza los efectos de la creación de los bancos hipotecarios en la asignación del crédito. El artículo muestra que los bancos hipotecarios operaron como intermediarios interregionales y facilitaron el acceso a crédito de largo plazo a dueños de propiedades inmuebles. Sin embargo, los bancos no ampliaron el acceso al crédito. Como los prestamistas privados, los bancos hipotecarios mayormente prestaron a comerciantes y propietarios de inmuebles de Lima y a hacendados de los principales valles costeros.

Palabras clave: Bancos, crédito hipotecario, América Latina, Perú

\section{INTRODUCTION}

In an economy without financial intermediaries, personal connections may be crucial for obtaining credit. Due to transaction costs and information asymmetries, families and firms may have to recur to their relatives, friends, business associates or neighbours to fund their consumption and investment. Also, due to transaction costs, borrowers have difficulty financing large and long-term projects. As financial intermediaries emerge, personal linkages become less relevant for accessing credit. In small societies, private credit markets (markets where transactions between savers and investors are direct) are socially efficient in the presence of fixed costs for financial intermediation. In large societies, however, financial intermediation and impersonal credit allocation lead to a more efficient allocation of resources, greater accumulation of capital and faster economic growth ${ }^{1}$.

A substantial number of historical studies discuss the role of early banks as financial intermediaries and their impact on the economy. Some argue that early banks contributed to the mobilisation of savings, leading to a more efficient allocation of financial resources. Bagehot (1873) and Hicks (1969), for example, argue that the financial system played a key role in the process of industrialisation of Great Britain by facilitating the mobilisation of capital for huge projects. In the same vein, Schumpeter (1934) argues that banks identified and funded entrepreneurs with the best chances of successfully implementing innovative products. More recently, Haber (1991) argues that

\footnotetext{
1 Several theoretical studies argue that a system with financial intermediaries is more efficient than a system without intermediaries due to transaction costs, information asymmetries, liquidity insurance and delegated supervision (Benston and Smith 1976; Leland and Pyle 1977; Bryant 1980; Diamond and Dybvig 1983; Diamond 1984).
} 
the lack of banks partly explains the slow industrialisation of Mexico and Brazil in the $19^{\text {th }}$ century ${ }^{2}$.

Other studies suggest a more moderate impact of banks. Some studies, for example, show that banks were not the first financial intermediaries in France and Mexico. Notaries played a role as financial intermediaries in these countries and helped - at least partly - to deal with transaction and information costs ${ }^{3}$. In addition, early banks did not necessarily broaden access to credit. Lamoreaux (1986) and Wang (2008), for example, argue that $19^{\text {th }}$-centrury banks in New England did not provide more general access to credit. Moreover, Zegarra (2014b) argues that the growth of exports in Latin America in the late $19^{\text {th }}$ and early $20^{\text {th }}$ centuries was exogenous to the development of banking.

One limitation of the literature is that only a few studies of early banks rely on micro-level data ${ }^{4}$. Several studies of early banking rely on country- or regional-aggregates of credit, banknotes, deposits and interest rates. Without micro-level data, however, it is hard to determine whether banks helped to cope with transaction costs by serving as financial intermediaries and whether banks broadened access to credit or improved loan terms.

This article uses a sample of notarised loans to explore the effects of the creation of mortgage banks in a small Latin American economy. In particular, it analyses the impact of mortgage banks on the allocation of credit in Peru in the 1860s and 1870s. The article shows that mortgage banks contributed to interregional financial intermediation and facilitated access to long-term credit for large estate owners. Banks, however, did not broaden access to credit.

This article constitutes an important contribution to the literature. First of all, it relies on micro-level data to determine the influence of mortgage banks on the allocation of credit ${ }^{5}$. Second, it analyses the role of banks in a Latin American economy; which is important considering the high levels of inequality in Latin America and the possible negative effects of inequality on financial development and economic growth. Third, it discusses the role of banks during the guano era, an important period in Latin American economic history. Several aspects of this period have received much attention. The study of mortgage banks, however, has not been widely studied ${ }^{6}$.

\footnotetext{
2 Other studies also support the hypothesis that banking influenced economic growth in Latin America (Triner 2000; Haber and Maurer 2002; Hanley 2005).

3 See Hoffman et al. (2012) for France and Levy (2012) for Mexico.

4 In recent decades, notarial records have been used to study credit markets (Beveridge 1985; Quinn 2001; Redish 2003; Hoffman et al. 2000; Levy 2012).

5 For Peru some micro-data studies have dealt with credit markets in the $19^{\text {th }}$ century, but not with the impact of mortgage banks (Zegarra 2013, 2014a, 2015).

6 Camprubí (1957) analyses the evolution of commercial banks in the guano era. Only Engelsen (1978) examines the importance of mortgage banks for coastal agriculture in Peru during the
} 
The structure of the article is as follows. Section 2 describes the data set. Section 3 describes the main characteristics of private lenders and mortgage banks during this period and the legislation that regulated their operations. Section 4 examines information imperfections in the private credit market. Section 5 analyses whether banks broadened access to credit. Section 6 examines whether banks contributed with interregional financial intermediation. Section 7 analyses the access to long-term credit and Section 8 concludes the article.

\section{THE DATA SET}

Notarial records constitute a rich source of information on mortgage credit markets in $19^{\text {th }}$-century Peru and are especially relevant for the study of real-estate mortgages in Peru. The Civil Code of 1851 dictated that real-estate mortgages could only be constituted by registration with a notary (by escritura pública), indicating the main obligation and the goods that secured the mortgage ${ }^{7}$. Notaries, however, not only registered information about real-estate mortgages, but also chattel mortgages and even general mortgages ${ }^{8}$. Nowadays, notarial archives are kept in the National Archives of Peru (Archivo General del Perú).

Notarised contracts include information on the names of the lenders and borrowers and the amount of the loan. In addition, most loans include the maturity of the loan, the interest rate and a description of the mortgaged property. Collateral could be real estate, merchandise, leasing contracts and even wages. For loans secured with urban estates, the contract usually indicated the name of the street where the estate was located. For loans secured with haciendas, the contracts usually included their names and the valleys where the haciendas were located. Some contracts also included the actual date of payment. Among loans granted by mortgage banks, the contracts also mentioned the purpose of the loan. Contracts also included information on the residence, occupations and civil status of some lenders and most borrowers. I complemented the information on residences and occupations with secondary sources, especially Fuentes $(1860,1863)$ and

\footnotetext{
(footnote continued)

guano era. Other studies deal with exports, economic growth and prices for the same period (Bonilla 1974; Gootenberg 1990; Hunt 2010).

7 In addition, mortgages had to be registered in the Oficina de Hipotecas (Office of Mortgages), managed by the Notary of Mortgages. These offices had existed from colonial times (GarcíaCalderón 1879, Vol. II, p. 1074). According to the Civil Code, there was an office in the capital city of every department (Peru was politically divided into departments; one of them was the department of Lima, with its capital in the province or city of Lima). Every Notary of Mortgages had to register the mortgages secured with estates from the department, indicating the owner of the estate, the value of the obligation, the lender, and the descriptions of the estate, the lender and borrower.

${ }^{8}$ General mortgages were loans that did not specify the collateral.
} 
TABLE 1

NUMBER OF CONTRACTS AND NOTARIES IN LIMA

\begin{tabular}{|l|c|c|c|c|}
\hline & $\mathbf{1 8 6 0 - 6 5}$ & $\mathbf{1 8 6 6 - 7 0}$ & $\mathbf{1 8 7 1 - 7 7}$ & Total \\
\hline $\begin{array}{l}\text { Number of contracts granted by private } \\
\text { lenders and mortgage banks }\end{array}$ & & & & \\
$\quad$ Sample & 1,337 & 959 & 1,339 & 3,635 \\
$\quad$ Population & 3,974 & 2,539 & 3,601 & 10,114 \\
Number of contracts granted by private & & & & \\
lenders & 1,337 & 867 & 959 & 3,163 \\
$\quad$ Sample & 3,974 & 2,299 & 3,120 & 9,393 \\
Population & & & & \\
Number of contracts granted by & 0 & 92 & 380 & 472 \\
mortgage banks & 0 & 240 & 481 & 721 \\
$\quad$ Sample & 2 & 2 & 2 & 2 \\
Population & 9.8 & 8.2 & 9.7 & 9.3 \\
Average number of notaries per year & & & \\
$\quad$ Sample & & & & \\
Population & & & & \\
\hline
\end{tabular}

Notes: The table reports the number of contracts under the titles of obligaciones, mutuos and hipotecas for the sample (loans notarised by José de Selaya and Felipe Orellana) and for the entire population of contracts. The information comes from the National Archives of Peru at Lima.

Lemale (1876). Contracts also indicated whether the lender and borrower were relatives.

To gather data, I first counted the number of contracts in all notaries under the titles of obligaciones, mutuos or hipotecas for 1860-1877 from January to December. All these contracts came from the National Archives of Peru in Lima. In total, I counted 10,114 contracts of these types for this period (Table 1). I then selected a sample of contracts. The sample comes from the two notaries with the longest series of notarial registration volumes (called protocolos) for 1860-1877: José de Selaya and Felipe Orellana. From these two notaries, I collected information from all contracts under the titles of obligaciones, mutuos or hipotecas from January to December ${ }^{9}$. To check for the representativeness of the sample, I look at contracts under the same titles from all notaries for 1870 .

I excluded from the sample those contracts that were not new loans. Some contracts under the titles of obligaciones and hipotecas were not loans; they were, for example, leasing contracts, labour contracts or other types of obligation which were not, in fact, loans. A few contracts were loans made in

${ }^{9}$ I read all contracts notarised by Selaya and Orellana. 
previous years. There are three reasons for the exclusion of old loans from the sample. First, it is not clear whether the amount of the debt includes only the principal or the principal and the unpaid interest. Second, the interest rates and maturity indicated in those contracts may not have reflected the supply and demand of funds, but the outcome of a renegotiation of the original debt. Third, in most cases, it is not possible to determine the year when the loan was originally granted. Now, most contracts (around 90 per cent) were new loans and so were included in the sample.

I selected the notaries of José de Selaya and Felipe Orellana because they were among the notaries that registered the largest number of loans. Overall, these notaries account for 36 per cent of all contracts in 1860-1877. Table 2 reports some statistics for the notaries of José de Selaya and Felipe Orellana (our sample). In addition, the table reports statistics for the population of loans for 1870. For 1870, among loans by private lenders, the notaries of Selaya and Orellana account for 34 per cent of all loans (131 out of 387) and 30 per cent of loans secured with real estate from Lima (forty-nine out of 163). In addition, among loans by mortgage banks, the sample accounts for 62 per cent of the loans in the population (sixty-nine out of 112).

Let us compare loans' characteristics between the sample and the population of loans for 1870. In particular, we will consider loans by private lenders. Loans secured with real estate were, on average, larger in the sample than in the population. However, in the case of loans secured with real estate from the province of Lima, the differences are far smaller; the average loan size in the sample $(3,365$ soles) is only 10 per cent greater than in the population ( 3,061 soles). On the other hand, there were important similarities in the distribution of loans in the sample and the population. For instance, in the sample, among all loans secured with real estate by private lenders, 39 per cent of loans in the sample were made by merchant lenders; in the population the percentage was 34 per cent. Furthermore, almost 100 per cent of loans in the sample and in the population were made by limeños (individuals living in the province of Lima), and around 90 per cent were made to limeños. The distribution of loans was also very similar among loans secured with real estate from the province of Lima.

Let us now consider loans by mortgage banks in 1870. The distribution of loans was similar in the sample and in the population. Among all loans, around 6 per cent went to merchants in the sample and in the population. Meanwhile, 75 per cent of loans in the sample and 80 per cent of loans in the population went to limeños. Importantly, both in the sample and in the population, loans by mortgage banks were far larger than loans by private lenders. Consider loans secured with real estate from the province of Lima. In the sample, mortgage banks made loans around 2.6 larger than private lenders. In the population, mortgage banks made loans almost seven times larger. The fact that mortgage banks made larger loans was not limited to the sample. 
TABLE 2

DESCRIPTIVE STATISTICS FOR THE SAMPLE AND THE POPULATION, 1870

\begin{tabular}{|c|c|c|c|c|c|c|c|c|c|c|c|}
\hline & & & & rivate len & & & & & ortgage $b$ & & \\
\hline & & $\begin{array}{c}\text { José } \\
\text { de } \\
\text { Selaya }\end{array}$ & $\begin{array}{c}\text { Felipe } \\
\text { Orellana }\end{array}$ & $\begin{array}{c}\text { The } \\
\text { sample }^{1}\end{array}$ & $\begin{array}{c}\text { Other } \\
\text { notaries }^{2}\end{array}$ & $\begin{array}{c}\text { All } \\
\text { notaries }\end{array}$ & $\begin{array}{c}\text { José } \\
\text { de } \\
\text { Selaya }\end{array}$ & $\begin{array}{c}\text { Felipe } \\
\text { Orellana }\end{array}$ & $\begin{array}{c}\text { The } \\
\text { sample }{ }^{1}\end{array}$ & $\begin{array}{c}\text { Other } \\
\text { notaries }^{2}\end{array}$ & $\begin{array}{c}\text { All } \\
\text { notaries }\end{array}$ \\
\hline $\begin{array}{l}\text { Number of contracts } \\
\text { under the titles of } \\
\text { obligaciones, mutuos or } \\
\text { hipotecas }\end{array}$ & (1) & 62 & 77 & 139 & 291 & 430 & 63 & 6 & 69 & 43 & 112 \\
\hline Number of loans & (2) & 59 & 72 & 131 & 256 & 387 & 63 & 6 & 69 & 43 & 112 \\
\hline $\begin{array}{l}\text { Number of loans as } \% \text { all } \\
\text { contracts }\end{array}$ & $\begin{array}{l}(3)= \\
(2) /(1)\end{array}$ & 95.2 & 93.5 & 94.2 & 88.0 & 90.0 & 100.0 & 100.0 & 100.0 & 100.0 & 100.0 \\
\hline $\begin{array}{l}\text { Loans secured with real } \\
\text { estate }\end{array}$ & & & & & & & & & & & \\
\hline $\begin{array}{l}\text { Number of loans } \\
\text { secured with real } \\
\text { estate }\end{array}$ & (4) & 26 & 37 & 63 & 177 & 240 & 63 & 6 & 69 & 43 & 112 \\
\hline $\begin{array}{l}\text { Number of loans } \\
\text { secured with real } \\
\text { estate as \% of all } \\
\text { loans }\end{array}$ & $\begin{array}{l}(5)= \\
(4) /(2)\end{array}$ & 44.1 & 51.4 & 48.1 & 69.1 & 62.0 & 100.0 & 100.0 & 100.0 & 100.0 & 100.0 \\
\hline Average loan size (soles) & & 7,374 & 2,299 & 4,394 & 2,697 & 3,142 & 21,284 & 3,717 & 19,757 & 37,220 & 26,461 \\
\hline Median loan size (soles) & & 2,200 & 828 & 1,280 & 1,200 & 1,200 & 6,400 & 3,250 & 6,000 & 10,000 & 7,100 \\
\hline $\begin{array}{l}\text { Average contracted } \\
\text { maturity (years) }\end{array}$ & & 1.6 & 1.6 & 1.6 & 2.0 & 1.9 & 20.0 & 20.0 & 20.0 & 20.0 & 20.0 \\
\hline $\begin{array}{l}\text { Average effective } \\
\text { maturity (years) }\end{array}$ & & 4.4 & 2.0 & 2.8 & 4.1 & 3.8 & 8.7 & 7.5 & 8.6 & 11.4 & 9.2 \\
\hline Average interest rate $(\%)$ & & 14.7 & 20.0 & 16.1 & 16.9 & 16.7 & & & & & \\
\hline $\begin{array}{l}\text { Percentage of loans by } \\
\text { merchant lenders }(\%)\end{array}$ & 3 & 76.4 & 9.1 & 38.5 & 31.3 & 33.6 & & & & & \\
\hline $\begin{array}{l}\text { Percentage of loans } \\
\text { to merchant } \\
\text { borrowers }(\%)\end{array}$ & 3 & 23.1 & 19.4 & 21.0 & 11.5 & 14.3 & 6.3 & 0.0 & 5.8 & 8.8 & 6.8 \\
\hline $\begin{array}{l}\text { Percentage of loans by } \\
\text { lenders from } \\
\text { Lima }(\%)\end{array}$ & 3 & 100.0 & 100.0 & 100.0 & 96.8 & 97.8 & & & & & \\
\hline $\begin{array}{l}\text { Percentage of loans to } \\
\text { borrowers from } \\
\text { Lima }(\%)\end{array}$ & 3 & 84.6 & 94.3 & 90.2 & 93.3 & 92.5 & 73.0 & 100.0 & 75.4 & 89.2 & 80.2 \\
\hline $\begin{array}{l}\text { Loans secured with real } \\
\text { estate from the province } \\
\text { of Lima }\end{array}$ & & & & & & & & & & & \\
\hline $\begin{array}{l}\text { Number of loans } \\
\text { secured with real } \\
\text { estate from the } \\
\text { province of Lima }\end{array}$ & (6) & 19 & 30 & 49 & 114 & 163 & 35 & 5 & 40 & 25 & 65 \\
\hline
\end{tabular}


TABLE 2 (Cont.)

\begin{tabular}{|c|c|c|c|c|c|c|c|c|c|c|c|}
\hline & & \multicolumn{5}{|c|}{ Private lenders } & \multicolumn{5}{|c|}{ Mortgage banks } \\
\hline & & $\begin{array}{c}\text { José } \\
\text { de } \\
\text { Selaya }\end{array}$ & $\begin{array}{l}\text { Felipe } \\
\text { Orellana }\end{array}$ & $\begin{array}{c}\text { The } \\
\text { sample }^{1}\end{array}$ & $\begin{array}{c}\text { Other } \\
\text { notaries }^{2}\end{array}$ & $\begin{array}{c}\text { All } \\
\text { notaries }\end{array}$ & $\begin{array}{c}\text { José } \\
\text { de } \\
\text { Selaya }\end{array}$ & $\begin{array}{l}\text { Felipe } \\
\text { Orellana }\end{array}$ & $\begin{array}{c}\text { The } \\
\text { sample }^{1}\end{array}$ & $\begin{array}{c}\text { Other } \\
\text { notaries }^{2}\end{array}$ & $\underset{\text { notaries }}{\text { All }}$ \\
\hline $\begin{array}{l}\text { Number of loans } \\
\text { secured with real } \\
\text { estate from the } \\
\text { province of Lima as } \\
\% \text { all loans }\end{array}$ & $\begin{array}{l}(7)= \\
(6) /(2)\end{array}$ & 32.2 & 41.7 & 37.4 & 44.5 & 42.1 & 55.6 & 83.3 & 58.0 & 58.1 & 58.0 \\
\hline Average loan size (soles) & & 5,929 & 1,742 & 3,365 & 2,929 & 3,061 & 9,477 & 4,060 & 8,800 & 40,728 & 21,080 \\
\hline Median loan size (soles) & & 2,000 & 800 & 1,040 & 1,200 & 1,200 & 6,000 & 4,500 & 5,400 & 8,000 & 6,000 \\
\hline $\begin{array}{l}\text { Average contracted } \\
\text { maturity (years) }\end{array}$ & & 1.7 & 1.7 & 1.7 & 2.3 & 2.1 & 20.0 & 20.0 & 20.0 & 20.0 & 20.0 \\
\hline $\begin{array}{l}\text { Average effective } \\
\text { maturity (years) }\end{array}$ & & 4.8 & 1.9 & 2.8 & 4.7 & 4.1 & 7.7 & 4 & 7.7 & 7.4 & 7.6 \\
\hline Average interest rate (\%) & & 15.5 & 17.9 & 17.1 & 16.9 & 16.9 & & & & & \\
\hline $\begin{array}{l}\text { Percentage of loans by } \\
\text { merchant lenders }(\%)\end{array}$ & 3 & 81.8 & 5.6 & 34.5 & 26.4 & 29.3 & & & & & \\
\hline $\begin{array}{l}\text { Percentage of loans } \\
\text { to merchant } \\
\text { borrowers }(\%)\end{array}$ & 3 & 21.1 & 20.0 & 20.4 & 10.5 & 13.9 & 2.9 & 0.0 & 2.5 & 11.8 & 5.2 \\
\hline $\begin{array}{l}\text { Percentage of loans by } \\
\text { lenders from Lima (\%) }\end{array}$ & 3 & 100.0 & 100.0 & 100.0 & 98.3 & 98.9 & & & & & \\
\hline $\begin{array}{l}\text { Percentage of loans to } \\
\text { borrowers from } \\
\text { Lima }(\%)\end{array}$ & 3 & 94.7 & 100.0 & 98.0 & 97.1 & 97.4 & 97.1 & 100.0 & 97.5 & 95.2 & 96.7 \\
\hline
\end{tabular}

Notes: The table reports summary statistics of the sample and the population of loans for 1870 .

${ }^{1}$ Contracts/loans notarised by José de Selaya and Felipe Orellana.

${ }^{2}$ It refers to all other notaries from the National Archives of Peru, office of Lima. They were José Cubillas, Juan de Cubillas, Manuel Iparraguirre, Miguel Lama, Francisco Palacios, Félix Sotomayor and Manuel Suárez.

${ }^{3}$ Taking into account observations with information.

${ }^{4}$ None of the contracts notarised by Felipe Orellana in 1870 secured with real estate from Lima had information on the effective maturity. 
Table 2 also shows that loans by the mortgage banks were far smaller in the sample than in the population. A more detailed look at these loans shows that loans by the Banco Territorial Hipotecario were of similar size in the sample and in the population, whereas loans by the Banco de Crédito Hipotecario were far smaller in the sample than in the population. Importantly, much of the difference in bank loan sizes is explained by a loan of 800,000 soles by the Banco de Crédito Hipotecario to a landlord with estates in Lima and other provinces notarised by Francisco Palacios. Excluding this loan, the average loan sizes in the sample and in the population are similar ${ }^{10}$. Moreover, further information for the Banco de Crédito Hipotecario suggests that the differences in average loan sizes between the sample and the population were not as large for other years as for 1870. According to a yearbook of the Banco de Crédito Hipotecario ${ }^{11}$, this bank made fifty-four loans secured with real estate from the department of Lima for a total amount of 926,900 soles in 1867 , so the average loan size was 17,165 soles. In 1868 , this bank made twenty-two loans secured with real estate from the department of Lima for an amount of 712,400 soles, with an average of 32,381 soles/loan. In the sample, the average loan size for the same type of loans (secured with real estate from the department of Lima) was 17,220 soles in 1867 and 57,475 soles in 1868 .

Table 3 shows the steps to estimate the number of loans, the number of lenders and borrowers and the value of new loans for the population for 1865 and 1872. Figure 1 depicts the number of loans secured with real estate from the province of Lima; Figure 2 depicts the number of lenders and borrowers for the same type of loans; Figure 3 depicts the size of these loans; and Figure 4 depicts the value of loans for each mortgage bank.

To estimate the total number of loans for the entire population, I first counted the total number of contracts for all notaries from Lima, distinguishing between two types of lenders: private lenders and mortgage banks. In a large number of notaries, I relied on the indexes of the registration volumes (protocolos), which indicate the type of contract and the type of lender. I included all contracts under the titles of obligaciones, mutuos and hipotecas. For notaries that did not have an index, I revised every page of the registration volumes to determine the number of contracts under the same titles.

For private lenders, to estimate the percentage of contracts that were new loans, I relied on the sample of loans from the notaries of José de Selaya and Felipe Orellana (line 5 in Table 3). I also estimated the number of loans secured with real estate from the province of Lima for the entire population (line 9). For mortgage banks, the sample shows that all contracts were new

10 The average loan size among notaries other than José de Selaya and Felipe Orellana would decline from 40,728 to 8,392 soles. Notice that the average in the sample is 8,800 soles.

11 This information comes from the Banco de Crédito Hipotecario (1869). 
TABLE 3

ESTIMATION OF THE NUMBER OF LOANS AND VOLUME OF CREDIT, 1865, 1872

\begin{tabular}{|c|c|c|c|c|c|}
\hline & \multicolumn{2}{|c|}{ Private lenders } & \multirow[b]{2}{*}{$\begin{array}{c}\text { Mortgage } \\
\text { banks (1872) }\end{array}$} & \multirow[b]{2}{*}{$\begin{array}{c}\text { BCH } \\
(\mathbf{1 8 7 2})\end{array}$} & \multirow[b]{2}{*}{$\begin{array}{c}\text { BTH } \\
\text { (1872) }\end{array}$} \\
\hline & 1865 & 1872 & & & \\
\hline \multicolumn{6}{|l|}{ Estimation of the number of loans } \\
\hline (1) Number of contracts in the population & 501 & 464 & 168 & 113 & 55 \\
\hline (2) Number of contracts in the sample & 187 & 159 & 142 & & \\
\hline $\begin{array}{l}\text { (3) Ratio number of contracts in the sample/contracts in } \\
\text { the population (line } 2 / \text { line 1) }\end{array}$ & 0.37 & 0.34 & 0.85 & & \\
\hline (4) Number of loans in the sample & 163 & 135 & 142 & & \\
\hline (5) Ratio loans/contracts in the sample (line 4/line 2) & 0.87 & 0.85 & 1.00 & 1.00 & 1.00 \\
\hline (6) Number of loans in the population (line $1 \times$ line 5 ) & 437 & 394 & 168 & 113 & 55 \\
\hline $\begin{array}{l}\text { (7) Number of loans secured with real estate from Lima } \\
\text { in the sample }\end{array}$ & 72 & 62 & 78 & & \\
\hline $\begin{array}{l}\text { (8) Ratio loans secured with real estate from Lima/all } \\
\text { loans (line 7/line 4) }\end{array}$ & 0.44 & 0.46 & 0.55 & $0.55^{1}$ & $0.55^{1}$ \\
\hline $\begin{array}{l}\text { (9) Number of loans secured with real estate from Lima } \\
\text { in the population (line } 6 \times \text { line } 8 \text { ) }\end{array}$ & 193 & 181 & 92 & 62 & 30 \\
\hline \multicolumn{6}{|l|}{$\begin{array}{l}\text { Estimation of the number of lenders and borrowers secured } \\
\text { with real estate from Lima }\end{array}$} \\
\hline (10) Number of lenders in the sample & 58 & 49 & 2 & & \\
\hline $\begin{array}{l}\text { (11) Ratio number of lenders/number of loans in the } \\
\text { sample (line 10/line 7) }\end{array}$ & 0.81 & 0.79 & & & \\
\hline (12) Number of lenders in the population (line $11 \times$ line 9) & 155 & 143 & 2 & & \\
\hline (13) Number of borrowers in the sample & 63 & 54 & 69 & & \\
\hline
\end{tabular}




\begin{tabular}{|c|c|c|c|c|c|}
\hline $\begin{array}{l}\text { (14) Ratio number of borrowers/number of loans in the } \\
\text { sample (line 13/line 7) }\end{array}$ & 0.88 & 0.87 & 0.88 & & \\
\hline $\begin{array}{l}\text { (15) Number of borrowers in the population (line } \\
14 \times \text { line } 9)\end{array}$ & 169 & 158 & 82 & & \\
\hline $\begin{array}{l}\text { Estimation of the value of credit for loans secured with real } \\
\text { estate from Lima }\end{array}$ & & & & & \\
\hline (16) Average loan size in the sample (soles) & 3,104 & 3,808 & 17,635 & $17,635^{1}$ & $17,635^{1}$ \\
\hline $\begin{array}{l}\text { (17) Value of new loans in the population (soles) (line } \\
16 \times \text { line 9) }\end{array}$ & 598,714 & 689,001 & $1,627,352$ & $1,094,588$ & 532,764 \\
\hline
\end{tabular}

Notes: BCH: Banco de Crédito Hipotecario, BTH: Banco Territorial Hipotecario.

The table shows the steps for the estimation of the number of loans and the value of new loans by private lenders and mortgage banks for 1865 and 1872 .

${ }^{1}$ For the estimation of the number and value of loans for each of the two mortgage banks, I assumed that the proportion of loans secured with real estate from Lima (line 8) and the average loan size (line 16) were the same in both banks. 
FIGURE 1

NUMBER OF LOANS SECURED WITH REAL ESTATE FROM LIMA

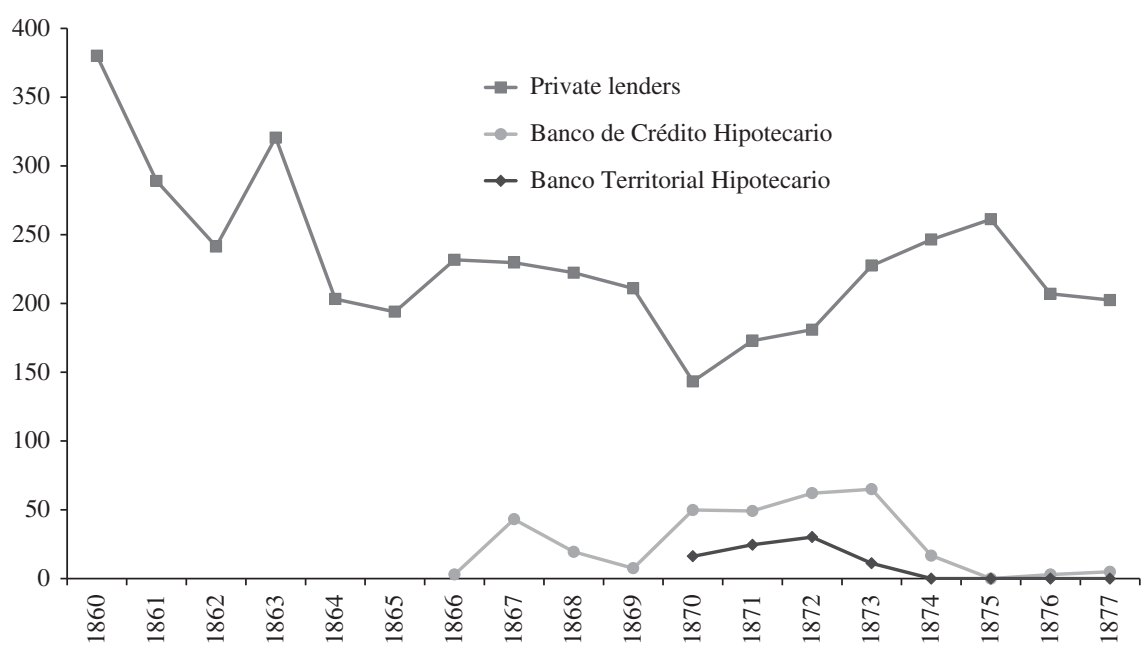

Notes: The figure depicts the number of loans secured with real estate from Lima. Table 3 shows the steps for the estimation of the number of loans.

loans (line 5). To estimate the number of loans by mortgage banks secured with real estate in the entire country and from Lima, I followed the same procedure as with private lenders (line 9). In addition, I estimated the number of lenders and borrowers (lines 12 and 15) taking into account the ratios of number of lenders/number of loans and number of borrowers/number of loans for the sample.

To estimate the volume of new loans (line 17), I multiplied the estimated total number of new loans by the sample average loan size for each type of lender. I made the assumption that average loan sizes from the sample reflect the average loan sizes for the population. Information for 1870 suggests that private lenders' loans secured with real estate from the province of Lima were of similar sizes in the sample and in the population (the difference was only 10 per cent). For mortgage banks, official information for 1867 and 1868 suggests that the differences were much smaller than for 1870 (Banco de Crédito Hipotecario 1869). Figures of new loans in constant soles were also calculated. To do so, I used the consumer price index from Seminario (2015, p. 855). The series of new loans was deflated with the price index.

To estimate the total level of outstanding loans in each year, it is important to distinguish between the contracted maturity of loans and the effective maturity or actual duration of the loans. Loan contracts usually indicated the maturity of loans (6 months, 1 year, etc.). In practice, however, 


\section{FIGURE 2}

NUMBER OF BORROWERS AND LENDERS FOR LOANS SECURED WITH REAL ESTATE FROM LIMA

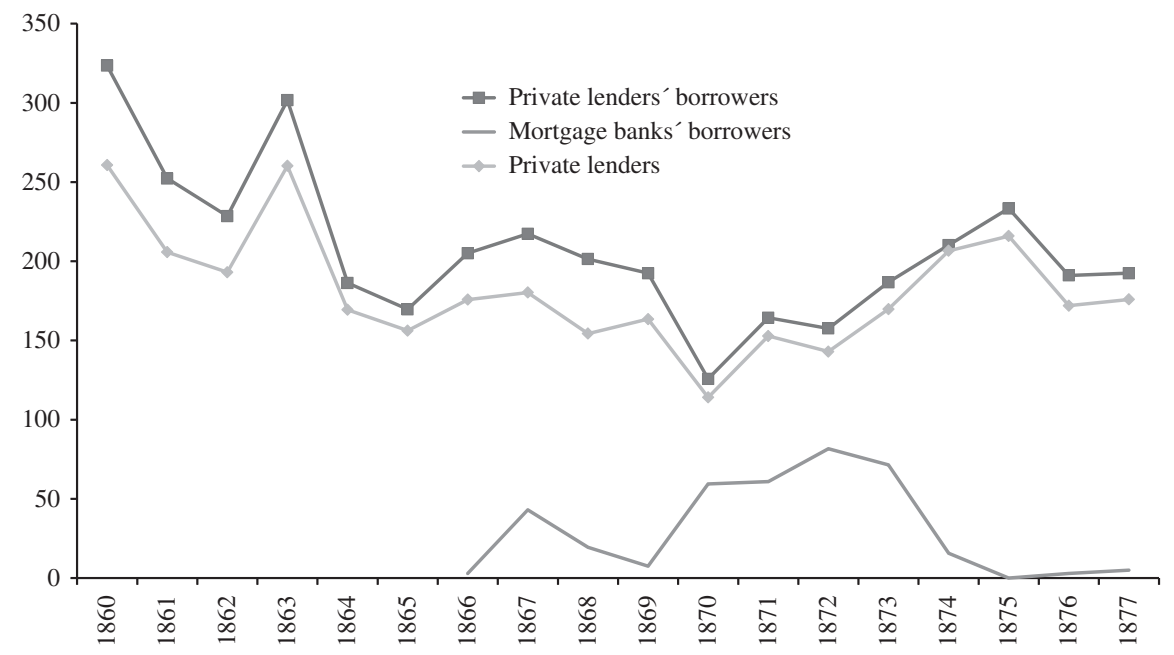

Notes: The figure depicts the number of borrowers and lenders for loans secured with real estate from Lima. Table 3 shows the steps for the estimation of the number of borrowers and lenders.

a significant number of borrowers repaid their loans prior to or after the due date. Contract maturity is the maturity that appeared in the contract, whereas effective maturity is the actual amount of time that borrowers took to repay their loans. To estimate the value of outstanding credit, I relied on the average effective maturity of loans, obtained from the sample of loans. Effective maturity was usually not a whole number so I then rounded the maturity to integers before estimating the value of outstanding credit.

I assumed that amortisation was uniform, that is, if the loans from a particular year were, on average, paid back in $d$ years, I then assumed that $1 / d$ of these loans were paid every year. In particular, I used the following formula to obtain the value of outstanding credit: $M_{t}=\sum_{j=0}^{\infty} \frac{d_{t-j}-j}{d_{t-j}} N_{t-j} I\left(d_{t-j}\right)$, where $M_{t}$ is the value of outstanding credit in year $t$ in soles, $N_{t}$ the value of new loans in year $t$ in soles, $d_{k}$ the average effective maturity (in years) of loans granted in year $k$ and $I\left(d_{t-j}\right)=1$ if $d_{t-j}>j$, and $I\left(d_{t-j}\right)=0$ otherwise $^{12}$. For private lenders, I was able to calculate the average effective

12 For example, if loans were always repaid in 1 year, then the outstanding credit was the same as the value of new loans. If loans always had a maturity of 3 years, then the value of outstanding credit in year $t$ was calculated as the one-third of the value of new loans in year $t-2$ plus two-thirds the value of new loans in year $t-1$ and plus the total value of new loans in year $t$. 
FIGURE 3

LOANS SECURED WITH REAL ESTATE FROM LIMA (MILLION SOLES)

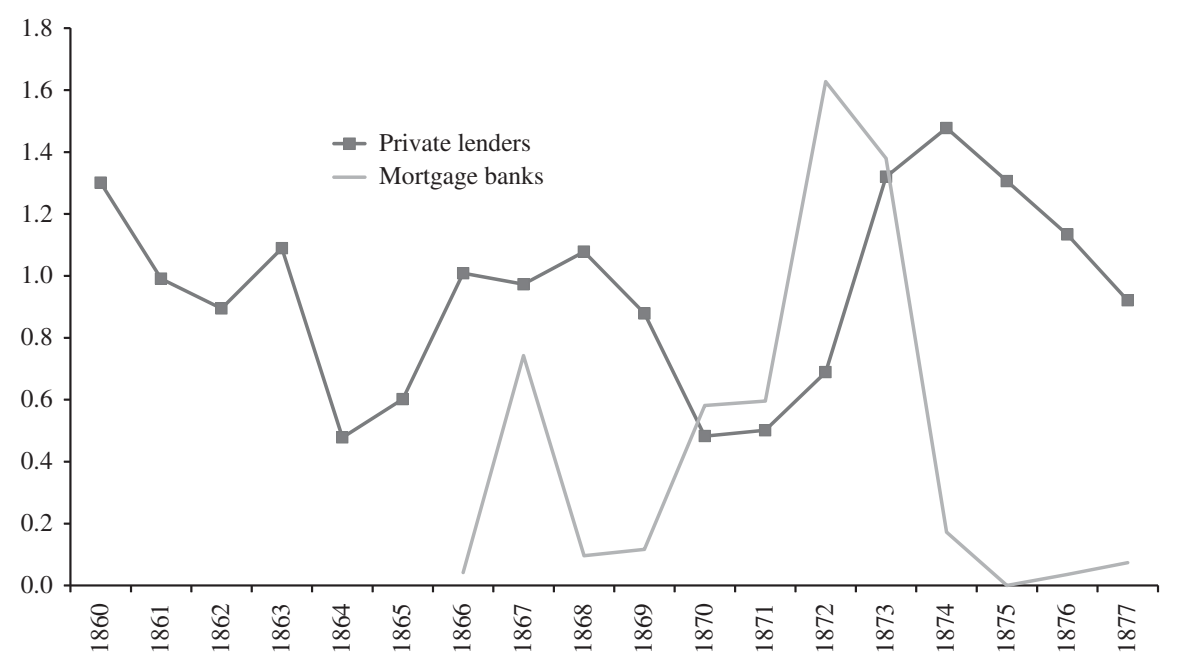

Notes: The figure depicts the value of loans (in current soles) secured with real estate from Lima. Table 3 shows the steps for the estimation of the value of credit.

maturity of loans for each year from the sample of loans. Loans by private lenders had an average effective maturity that ranged between 2 and 4 years. For mortgage banks, I was able to estimate the average effective maturity of loans for most years. The only years for which there is no information for the actual duration of the loans are 1866 and 1875. I assumed that the average maturity in 1866 was the same as for 1867 and that the maturity in 1875 was equal to the simple average of the actual maturities of 1874 and 1876 . On average, effective maturity of loans by mortgage banks was around 8 years. Figure 4 depicts the evolution of outstanding credit for private lenders and mortgage banks in current soles. To obtain the level of outstanding credit in constant soles of 1876, I first calculated the series of new loans in constant soles of 1876 and then proceeded as indicated in this paragraph.

To estimate the concentration of new loans among borrowers, I calculated four indicators. Considering that loans by private lenders were substantially smaller than loans by mortgage banks and that the ratio number of private lenders' loans/number of mortgage banks' loans is lower for the sample than for the population, it is important to adjust the sample before calculating the concentration indexes. For 1870, the ratio number of private lenders' loans/ number of mortgage banks' loans is equal to 1.2 for the sample and 2.5 for the population. I then duplicated the sample for private lenders' loans for every year $t$. If the original sample had $N$ private lenders' loans for year $t$, the new 
FIGURE 4

VALUE OF LOANS SECURED WITH REAL ESTATE FROM LIMA (MILLION SOLES)

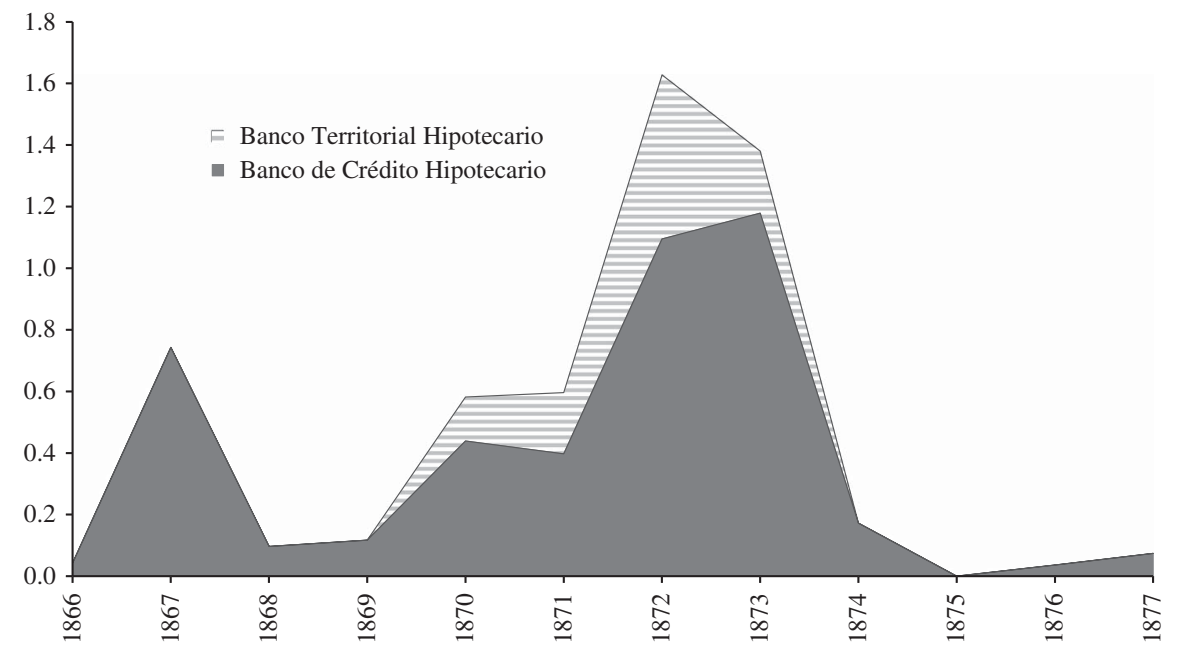

Notes: The figure depicts the value of loans (in current soles) secured with real estate from Lima. Table 3 shows the steps for the estimation of the value of credit.

sample had $2 N$ loans by private lenders with the same loan sizes ${ }^{13}$. I made the assumption that the borrowers in the first $N$ loans were not the same as the borrowers in the additional $N$ loans ${ }^{14}$. I also made the assumption that the distribution of borrowers in the original sample was the same as in the additional loans ${ }^{15}$. On the other hand, I did not adjust the original sample for mortgage banks. With these changes, the proportion of loans by private lenders in the total number of loans increases; if the original sample had $N$ loans by private lenders and $M$ by mortgage banks, the adjusted sample had $2 N$ loans by private lenders and $M$ loans by mortgage banks. I calculated the concentration indexes with the new adjusted sample. Figure 5 depicts the evolution of the four indicators.

13 For example, if the original sample has $M 1+M 2+M 3$ loans by private lenders ( $M 1$ loans of 1,000 soles, $M 2$ loans of 2,000 soles and $M 3$ loans of 3,000 soles), the adjusted sample has $2 \times(M 1+M 2+M 3)$ loans by private lenders $(2 \times M 1$ loans of 1,000 soles, $2 \times M 2$ loans of 2,000 soles and $2 \times$ M3 loans of 3,000 soles).

${ }^{14}$ This assumption is consistent with the data for 1870 . For this year, I noticed that only one borrower appeared in loans notarised by José de Selaya or Felipe Orellana (the sample) and in loans notarised by other notaries.

15 For example, if one borrower accounted for 10 per cent of the original $\mathrm{N}$ loans, then in the adjusted sample of $2 \mathrm{~N}$ loans (the original sample plus the additional loans) two different borrowers accounted for 10 per cent of the $2 \mathrm{~N}$ loans. 
FIGURE 5

OUTSTANDING LOANS SECURED WITH REAL ESTATE FROM LIMA (MILLION SOLES)

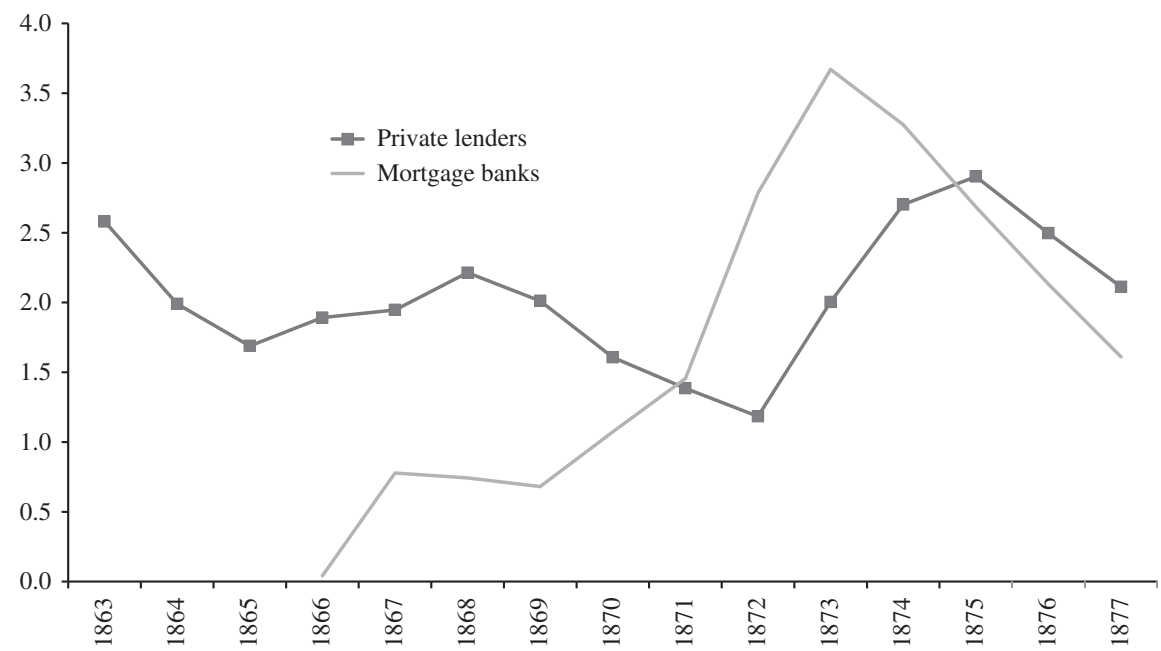

Notes: The figure depicts the value of loans (in current soles) secured with real estate from Lima. See the text for a discussion of the methodology to estimate outstanding credit.

Finally, I also analysed notarised loans by commercial banks. To estimate the value of loans made by these banks, I made the assumption that the average loan sizes were similar to those for mortgage banks. Our calculations indicate that commercial banks only accounted for 5 per cent of the total volume of new loans and 1.2 per cent of the number of contracts (obligaciones, mutuos and hipotecas) in 1860-1877. As commercial banks rarely made mortgage loans, the article only focusses on loans by private lenders and mortgage banks.

\section{THE FINANCIAL SECTOR IN THE GUANO ERA}

For two decades after independence in 1821, Peru experienced commercial stagnation. From the late 1840s, however, the country's economic situation changed dramatically due to the exploitation of guano reserves (Table 4). In particular, exports grew from 4.8 million soles in 1845 to thirty-five million soles in 1860 and the trade balance reached twenty million soles in 1860 . Through the $1860 \mathrm{~s}$, as the trade balance was positive and payments on foreign government debt (amortisation and interests) were relatively low, the Peruvian economy experienced an inflow of specie (Zegarra 2013, p. 190). The situation changed in the late 1860s and 1870s. 
TABLE 4

THE PERUVIAN ECONOMY, 1840-75

\begin{tabular}{|c|c|c|c|c|c|c|c|c|c|}
\hline \multirow{2}{*}{\multicolumn{10}{|c|}{ Foreign commerce }} \\
\hline & & & & & & & & & \\
\hline Exports (million current soles) & (A) & 5.2 & 4.8 & 7.6 & 10.3 & 35.0 & 25.7 & 21.0 & 19.0 \\
\hline Imports (million current soles) & (B) & 4.7 & 5.1 & 6.0 & 9.1 & 15.0 & 15.0 & 12.0 & 16.0 \\
\hline Trade balance (million current soles) & (A) $-(\mathrm{B})$ & 0.5 & -0.3 & 1.6 & 1.2 & 20.0 & 10.7 & 9.0 & 3.0 \\
\hline \multicolumn{10}{|l|}{ GDP and prices } \\
\hline GDP of Peru (million constant soles of 1876) & & 131.6 & 146.2 & 164.5 & 206.5 & 233.6 & 240.8 & 315.3 & 326.1 \\
\hline Consumer price index $(1876=100)$ & & 42.9 & 40.0 & 40.0 & 44.0 & 65.5 & 69.5 & 79.4 & 78.6 \\
\hline \multicolumn{10}{|l|}{$\begin{array}{l}\text { Loans secured with real estate from the } \\
\text { province of Lima }\end{array}$} \\
\hline Value of new loans (million current soles) & & & & & & 1.3 & 0.6 & 1.1 & 1.3 \\
\hline $\begin{array}{l}\text { Value of new loans (million constant soles of } \\
1876)^{1}\end{array}$ & & & & & & 2.0 & 0.9 & 1.3 & 1.7 \\
\hline Outstanding credit (million current soles) & & & & & & & 1.7 & 2.7 & 5.6 \\
\hline $\begin{array}{l}\text { Outstanding credit (million constant soles of } \\
\qquad 1876)^{1}\end{array}$ & & & & & & & 2.7 & 3.4 & 6.9 \\
\hline Outstanding credit/GDP of $\mathrm{Peru}^{2}$ & & & & & & & 0.011 & 0.011 & 0.021 \\
\hline Outstanding credit/exports of Peru ${ }^{3}$ & & & & & & & 0.066 & 0.128 & 0.294 \\
\hline
\end{tabular}

Notes: Figures are in silver soles. The source for foreign commerce is Mitchell (1993, pp. 432, 434). Original figures on foreign commerce are in silver pesos (1840-60) and silver soles (1865-75). Exports and imports for 1840, 1850 and 1865 were estimated using interpolation. As silver pesos (unlike Bolivian pesos) and soles had the same specie content, figures in silver pesos were converted to soles using the exchange ratio 1 peso $=1$ sol. The source for GDP is Seminario (2015, pp. 889-893). Credit was deflated with the price index published by Seminario (2015, p. 855).

${ }^{1}$ The value of new loans in constant soles was obtained deflating the value of new loans in current soles with the price index $(1876=100)$. Outstanding credit in constant soles was obtained by first deflating the value of new loans for all years and then following the same steps as described in the text.

${ }^{2}$ The ratio outstanding credit/GDP was obtained using the level of outstanding credit secured with real estate from Lima and GDP of Peru in constant soles of 1876 .

${ }^{3}$ The ratio outstanding credit/exports was obtained using the level of outstanding credit secured with real estate from Lima and exports of Peru in current soles. 
After reaching a peak in the early 1860s, the export sector experienced a downturn due to the decline in the prices and quality of guano reserves. Exports declined to twenty-one million soles in 1870 and nineteen million in 1875. Importantly, the trade balance declined to only three million soles in 1875, deteriorating the balance of payments (Zegarra 2013, p. 201).

The evolution of the Peruvian economy had an impact on the financial system. Prior to 1860 , families and firms in need of funds only obtained credit from private lenders. Private lenders were an important source of credit in colonial Peru (see, e.g. Suárez 2001). Banks of issue and mortgage banks only appeared in Peru after 1860, at a time of export boom and abundance of specie. However, as exports declined in the late 1860s and 1870 s, banking activity experienced a significant downturn; furthermore, as Peru entered into war against Chile (1879-1883), most banks closed down.

Private lenders were individuals or companies that lent their own funds. Most private lenders were merchants and large estate owners, the economic elite of Peru. In 1860-1877, around 35 per cent of loans were provided by merchants while urban proprietors made 8 per cent of all loans. Excluding loans with missing information on lenders' occupations, merchants would account for around 56 per cent of the number of loans (Table 5).

Private lenders allocated loans subject to the general commercial and civil legislation. Until the mid-19 $9^{\text {th }}$ century, contracts - including loans - were made subject to traditional civil and commercial practices. In the early 1850 s, however, civil and commercial codes were enacted to regulate all types of contracts, including loans. According to the Civil Code of 1851, private lenders could make loans secured with any asset. There were no capital requirements for private lenders, no restrictions on loan size, and no interest rate caps. There were certainly some requirements for lending and borrowing but with some exceptions, most mentally healthy adults could lend or borrow ${ }^{16}$.

Real-estate mortgages could only be constituted by a notary (by escritura pública). To be valid, real-estate mortgages had to specify the amount of the loan and the mortgaged estate, and had to be registered in local Oficinas de Hipotecas ${ }^{17}$. Information on mortgaged estates was supposed to be clear, thereby reducing informational deficiencies. In several cases, however, the staff in the Oficinas de Hipotecas was not responsible, and the registration books were not well organised, leading to deficiencies and confusion (GarcíaCalderón 1868, pp. 33-36).

Loans by private lenders were secured with a wide variety of assets. Depending on the guarantee, mortgages could be «general» or «special». Practically, all loans indicate that the borrower would secure the loan with

16 Single women had the same rights as men; whereas married women could lend and borrow with the authorisation of their husbands.

17 These Oficinas de Hipotecas were government offices in charge of registering mortgages in each department. Mortgages had to be registered in the Oficinas where the mortgaged estate was located. 
TABLE 5

DISTRIBUTION OF LOANS BY PRIVATE LENDERS, 1860-77 (\%)

\begin{tabular}{|l|r|r|r|r|}
\hline \multirow{2}{*}{} & \multicolumn{2}{|c|}{ All loans } & \multicolumn{2}{c|}{$\begin{array}{c}\text { Loans secured } \\
\text { with real estate }\end{array}$} \\
\cline { 2 - 5 } & \multicolumn{1}{|c|}{$\mathbf{N}$} & \multicolumn{1}{|c|}{ F } & N & \multicolumn{1}{c|}{ F } \\
\hline Residence of lenders & & & & \\
Province of Lima & 66.8 & 78.8 & 65.3 & 77.1 \\
Other provinces of the department of Lima & 0.2 & 0.1 & 0.2 & 0.2 \\
Callao & 0.8 & 0.5 & 1.1 & 0.5 \\
Northern coast & 0.6 & 0.4 & 0.8 & 0.6 \\
Southern coast & 0.7 & 1.5 & 1.0 & 2.3 \\
Highlands and jungle & 0.6 & 0.5 & 0.6 & 0.5 \\
Other countries & 0.4 & 0.5 & 0.2 & 0.2 \\
Non-identified & 29.9 & 17.7 & 30.7 & 18.5 \\
Occupation of lenders & & & & \\
Merchants & 35.4 & 53.6 & 28.5 & 49.6 \\
Artisans and manufacturers & 1.9 & 0.7 & 2.4 & 1.1 \\
Landowners, agriculturists and miners & 5.0 & 6.0 & 5.5 & 5.6 \\
Military personal & 3.7 & 3.6 & 3.7 & 5.1 \\
Public bureaucracy & 2.7 & 1.6 & 2.9 & 1.6 \\
Members of religious institutions & 1.1 & 0.9 & 1.5 & 1.4 \\
Professionals (lawyers, medical doctors and & 5.0 & 6.4 & 5.6 & 5.5 \\
professors) & & & & \\
Urban real-estate proprietors & 8.3 & 4.5 & 10.6 & 5.6 \\
Public institutions and charities & 0.2 & 0.2 & 0.4 & 0.4 \\
Non-identified & 20.8 & 11.4 & 25.3 & 13.8 \\
Gender & 5.3 & 15.1 & 4.7 & 12.1 \\
Male & 22.6 & 38.8 & 24.2 \\
Female & & & \\
Companies & & 73.5 & 69.9 & 74.1 \\
\hline
\end{tabular}

Notes: The table reports the distribution of loans (in percentage points) by private lenders, according to the residence of lenders, the location of collateral, the occupation of lenders, and gender of lenders. The information comes from the notaries of José de Selaya and Felipe Orellana.

all present and future assets. If a loan was only secured with «all present and future assets», then the contract was called a "general mortgage». Most contracts, however, also include a precise specification of the collateral. Collateral consisted of real-estate properties, leasing contracts, capital goods, 
TABLE 6

DISTRIBUTION OF LOANS BY TYPE OF SECURITY, 1860-77

\begin{tabular}{|l|r|}
\hline & $\%$ \\
\hline Special mortgages & \\
Urban estates & 51.1 \\
Rural estates & 9.4 \\
Urban chattel mortgages & 9.3 \\
Rural chattel mortgages & 3.0 \\
Wages & 6.3 \\
Others & 3.6 \\
General mortgages & 12.4 \\
Non-specified & 4.9 \\
\hline
\end{tabular}

Notes: The table reports the percentages of loans by private lenders, according to the type of collateral. The information comes from the notaries of José de Selaya and Felipe Orellana for 1860-77.

merchandise, and even the borrower's salary. If a loan was secured with a specific asset, the contract was called a «special mortgage». The use of precise collateral may have given lenders a more secure claim than general mortgages. According to the Civil Code, the mortgaged asset had to be specified and registered; otherwise, it would have no value (García-Calderón 1879, Vol. II, p. 1073).

Most private lenders' loans were secured with urban real estate (Table 6). In 1860-1877 >50 per cent of all loans by private lenders were secured with urban estates, and only 9 per cent were secured with rural estates. In addition, 12 per cent of loans were urban or rural chattel mortgages (secured with leasing contracts, capital goods and merchandise). Interestingly, 6 per cent were secured with the debtors' wages. An important number of loans by private lenders (accounting for 12 per cent of the total number of loans) constituted general mortgages.

Commercial banks were banks that could issue and discount notes. The first commercial banks started to operate in the early 1860s. By late 1862 the Banco de la Providencia opened an office in Lima. In 1863 two other banks opened offices and by 1872 there were eleven commercial banks operating in the entire country. Commercial banks were subject to the general civil and commercial legislation. These banks grew substantially in the late 1860s and early 1870s. In spite of the abundant equity, however, these commercial banks did not grant many loans secured with real estate ${ }^{18}$. The main shareholders of these banks of

18 According to our estimates, for example, commercial banks only accounted for 5 per cent of the value of total mortgage credit in 1860-1877. Consistently, the evidence for France also indicates that commercial banks did not compete in the mortgage market (Hoffman et al. 2015). 
issue were members of Peru's commercial elite. As Camprubí (1957) indicates, merchants extended their economic activities through the banking business.

The first mortgage bank, the Banco de Crédito Hipotecario, was chartered in 1866 by a special Supreme Decree. This charter regulated the operations of the mortgage bank, clearly specifying its rights and obligations. The mortgage bank would start operations with a capital of one million soles. This bank was not allowed to issue banknotes or receive deposits; rather it funded credit with the issue of mortgage bonds. Total issue of bonds could not exceed four times the capital stock. The bank would grant loans for no more than 20 years, loans could not be of $<500$ soles, and the size of loans could not exceed 50 per cent of the value of collateral.

The charter indicated that the borrower had to pay twenty annuities, payable in four parts, every 3 months. The initial charter established that the annuities would be 12 per cent of the amount of the loan. The bank, however, did not provide specie to borrowers; it gave mortgage bonds to their borrowers, which could be exchanged for cash in the marketplace. These bonds would pay an interest rate of 8 per cent per year (Paz Soldán 1887, pp. 8-16). In addition, the bank charged a registration fee of 2.5 per cent. From our sample of loans, the bank always opted for charging an annuity of 12 per cent ${ }^{19}$. This payment included interest and the amortisation of the debt. The bank granted loans in mortgage bonds but had to be repaid in specie. In contrast, practically all contracts for private lenders indicated that loans were granted in specie and had to be repaid also in specie. In times of scarcity of specie, however, some bank debtors did not intend to repay their debts in specie. In 1880 and 1881, for example, the Banco de Crédito Hipotecario amortised mortgage bonds with depreciated fiscal paper money for 5.1 million soles (Paz-Soldán 1887, p. V). By 1884, a number of borrowers of Banco de Crédito Hipotecario intended to repay the loans in depreciated paper money as if it were equivalent to specie (Banco de Crédito Hipotecario 1884, p. 6).

On the other hand, the charter imposed some restrictions on the use of loans. It established that the bank could only grant loans secured with real estate, and that the purpose of the loan would be the payment of previous mortgages, the purchase of real estate or the improvement of the property. In addition, loans could only constitute first mortgages, so the bank had the priority over all other claims on the mortgaged properties in the event of default $^{20}$.

\footnotetext{
19 And paying an interest rate of 8 per cent to bondholders.

20 In addition, the charter established steps towards the repossession of collateral in case of default. If, having been judicially requested, the debtor did not pay the three monthly quota or quotas within the period of 30 days, the bank could request the repossession of the mortgaged property or its foreclosure. Once the bank showed that the debtor did not meet its obligation, the repossession of the property would be ordered by the judge within a period of 30 days. The resolution of the judge would be executed immediately regardless of a possible appeal, and the judge
} 
TABLE 7

MAIN SHAREHOLDERS OF THE BANCO DE CRÉDITO HIPOTECARIO

\begin{tabular}{|l|l|}
\hline Shareholders with at least 40 shares & Shareholders with at least 10 shares \\
\hline Buevantura Elguera & José Mansueto Canaval \\
Ramón Montero & Manrique Swayne \\
Juan Manuel Montes & José Domingo Castañeda \\
Manuel Montero & José G. Seacome \\
José Vicente Oyague y Hermano & Julián de Zaracondegui \\
Pedro Denegri & José de la Riva Agüero \\
Delgado Hermanos e Hijos & Francisco García Calderón \\
Carlos Gonzales de Cámdamo & \\
Juan Mariano Goyeneche y Gamio & \\
José Canevaro e Hijos & \\
Antonio Joaquín Ramos & \\
Sescau Valdeavellano y Cia & \\
\hline
\end{tabular}

Note: One share of this bank had a nominal value of 1,000 soles. Source: El Comercio, 20 August 1866.

The capital of the Banco de Crédito Hipotecario was initially one million soles and there was a great demand for its shares; they were all sold in 24 hours. The capital was then raised to 1.5 million soles. By 1873 the capital had already reached three million soles. Just like the shareholders of the banks of issue, the main shareholders of the Banco de Crédito Hipotecario were important merchants, urban proprietors and hacendados from Lima and other coastal provinces (Table 7$)^{21}$. The members of the Board of Directors were important merchants, railroad investors, large estate owners and some had previously participated in the credit market as private lenders or as shareholders of commercial banks (Table 8). Among the directors of the Banco de Crédito Hipotecario, for example, José Domingo Castañeda had railroad interests (Meiggs 1871, p. 483) and Pedro Denegri had investments in railroad and banking businesses ${ }^{22}$. Denegri was also an important private lender; in our records, twenty-six loans were made by Denegri between 1860

\footnotetext{
(footnote continued)

would mandate the foreclosure of the estate if the bank requested it. We do not have evidence, however, on the effectiveness of these privileges. It is possible that the procedures established by the charter to reduce the probability of default were not followed in practice by the judiciary system.

21 Camprubí (1957, p. 62). According to the statutes of the bank, it was necessary to have at least forty shares $(40,000$ soles $)$ to be a member of the Board.

22 He was one of the ten founders of Banco del Perú in 1863 (Camprubí 1957). For the reference on railroads, see Meiggs (1871, p. 483).
} 
TABLE 8

BOARDS OF DIRECTORS AND MANAGERS OF THE TWO MORTGAGE BANKS

\begin{tabular}{|l|l|}
\hline Banco de Crédito Hipotecario, 1866 & Banco Territorial Hipotecario, 1869 \\
\hline Board of Directors & Board of Directors \\
José Domingo Castañeda & Buenaventura Elguera \\
Pedro Denegri & Francisco García Calderón \\
Dionisio Ortiz de Villate & José Amancio Castillo \\
José Barrón & Domingo Laos \\
Carlos Delgado & Antonio Araoz \\
Manager & Manager \\
José de la Riva Agüero & Enrique Perla \\
\hline
\end{tabular}

Notes: The table reports the first Boards of Directors of the Banco de Crédito Hipotecario in 1866 and the Banco Territorial Hipotecario in 1869.

Source: Camprubí (1957, pp. 63, 86).

and 1865. Dionisio Ortiz de Villate was an important merchant and estate owner, and made loans in the early 1860s (McEvoy 2004, p. 254). José de la Riva Agüero, the manager of the bank, was also an important merchant, railroad investor and estate owner (Meiggs 1871, p. 483; McEvoy 2004, p. 254).

The charter of the Banco de Crédito Hipotecario also established that other mortgage banks could operate under the same conditions. In 1869, Congress enacted a law confirming that all mortgage banks would be subject to the same privileges and obligations as that mortgage bank in order to foster the "progress of agriculture and the repair of urban estates»" ${ }^{23}$. The same year, a second mortgage bank, the Banco Territorial Hipotecario, was authorised to operate. The fact that this bank was subject to the same regulations as the Banco de Crédito Hipotecario is confirmed by its charter (Banco Territorial Hipotecario 1870). The creation of the Banco Territorial Hipotecario, with a capital of one million soles, was also received with optimism. The shares of the Banco Territorial Hipotecario were sold with a premium of 10 per cent over the nominal value. In this case, the main shareholders also belonged to the commercial and business elite (Camprubí 1957, pp. 85-86).

Commercial and mortgage banks experienced an important expansion in the late 1860s and early 1870s. Total short-term credit increased from 5.4 million soles in 1865 to twenty-eight million soles in 1872 (Camprubí 1957; Zegarra 2006). As Quiroz indicates, "the sudden inflow of foreign capital triggered a temporary banking boom between 1869 and 1872» (1993, p. 38). From 1866 mortgage banks offered long-term loans secured with real estate. Overall, the number of loans by mortgage banks increased from

${ }^{23}$ Law enacted on 4 February 1869. 
fifteen in 1869 to 168 in 1872, and the total value of new loans increased from 258,000 soles in 1869 to 4.7 million soles in 1872. The evolution of bank credit in Lima was similar to that in the country as a whole. Considering loans secured with estates located in the province of $\mathrm{Lima}^{24}$, the number of loans by the two mortgage banks increased from eight in 1869 to ninety-two in 1872, and the number of borrowers increased from eight in 1869 to eightytwo in 1872 (Figures 1 and 2). In addition, the estimated value of new loans granted increased from 117,000 soles in 1869 to 1.63 million soles in 1872, and outstanding credit increased from 681,000 soles in 1869 to 3.7 million soles in 1873 (Figures 3, 4 and 5).

In the meantime, private lenders experienced a decline in their operations in Lima in 1866-1872. Credit by mortgage banks overcompensated for the reduction in private lenders' credit activity, and the total amount of new loans in the province of Lima (taking into account mortgage banks and private lenders) increased by 350 per cent between 1865 and 1873; whereas total outstanding credit in Lima in 1873 was 3.4 times as much as in 1865. Interestingly, the growth of credit was far superior to the growth of the economy. The ratio credit secured with real estate from Lima/GDP of Peru grew from 0.011 in 1865 to 0.021 in 1873 , whereas the ratio credit secured with real estate from Lima/exports of Peru grew from 0.066 in 1865 to 0.294 in $1873^{25}$.

The credit market was apparently affected by the decline of exports and the consequent decline in the inflow of specie in the 1870s. Camprubí (1957) and Zegarra (2013) indicate that commercial banks found it difficult to face the demand for specie from their note holders. By 1873, the government borrowed funds from some commercial banks in exchange for the acceptance of the banks' notes in the public offices. By 1875, the main commercial banks suspended convertibility of their banknotes. In 1877, considering the impossibility of the four banks to redeem their notes into specie, the government assumed the debt of these banks for the issue of banknotes ${ }^{26}$. Mortgage banks also experienced a decline in their activity ${ }^{27}$. According to

${ }^{24}$ These loans include downtown Lima, the small towns or villages of Chorrillos, Miraflores, Barranco, Surco and Magdalena and the nearby haciendas.

${ }_{25}$ As I compare credit secured with real estate from Lima with GDP and exports for the entire country, these ratios do not reflect the degree of financial deepening. They are only useful as an indicator of how the deepening may have changed over time. To have an indicator of financial deepening, one would need the GDP of Lima.

${ }^{26}$ For a discussion on the banking crisis in the mid-1870s, see Camprubí (1957) and Zegarra (2013)

27 The crisis of the commercial banking sector - manifested by the suspension of convertibility of banknotes in 1875 and the conversion of banknotes into fiscal paper money in 1877 - probably led to a decline in the confidence in financial intermediation. The market value of the mortgage bonds declined consistently from the mid-1870s. By 1883, the Banco de Crédito Hipotecario indicated that the discount was 63 per cent (Banco de Crédito Hipotecario 1883, p. 14.), and 1 year later the managers of the two mortgage banks indicated that it was unlikely for the discount to be $<50$ per cent in the future (Gallagher and Espinoza 1885, p. 4). As banks loaned mortgage bonds at a fixed 
our calculations, the estimated value of new loans by mortgage banks in the country as a whole declined from 4.7 million soles in 1872 to 292,000 soles in 1874 and 74,000 soles in $1877^{28}$. In 1881, the Banco de Crédito Hipotecario suspended operations and its accounts were subsequently liquidated ${ }^{29}$. The Banco Territorial Hipotecario followed a similar trend (Camprubí 1957, pp. 414-415). The activity of Lima's private lenders also declined; total outstanding loans by private lenders fell from 2.7 million soles in 1874 to 2.1 million in 1877. Overall, total credit secured with real estate in Lima offered by banks and by private lenders — declined from 1873 .

In summary, prior to the creation of mortgage banks, private lenders offered loans to merchants, renters and individuals from other occupations. Commercial and mortgage banks expanded their activities in the 1860s and early 1870s. Private lenders then lost relative importance. From the mid1870s, however, banks experienced a significant decline in their allocation of credit.

\section{PRIVATE LENDERS AND MARKET IMPERFECTIONS}

Economic theory suggests that in the absence of financial intermediaries, market imperfections limit the development of impersonal credit markets. When financial transactions are direct, borrowers face transaction costs when they seek lenders and asymmetric information makes it costly for private lenders to know whether borrowers are good credit risks. If transaction and information costs are very high, private lenders will opt for lending to their relatives, their friends, their neighbours, as well as to borrowers from the same occupations and from the same city. Does the evidence indicate that personal linkages were important in granting loans in the private credit market?

In the private credit market of Lima, lenders and borrowers may have found it efficient to conduct financial transactions with individuals with similar occupations to offset transaction and information costs. As indicated previously, merchants constituted the main source of funding in the private credit market of Lima; merchant lenders accounted for 54 per cent of the value of credit in 1860-1877 (Table 5) ${ }^{30}$. In the presence of transaction and

\footnotetext{
(footnote continued)

interest rate, debtors may have found it more expensive to borrow from banks than from private lenders. Scattered evidence shows that some families were even motivated to borrow from private lenders in order to repay their debt with mortgage banks, which was possible under the statutes of the two banks.

28 According to the Banco de Crédito Hipotecario (1876), this bank only made three loans in 1875 for a total amount of 172,000 soles in 1875 .

${ }^{29}$ In its yearbook of 1883, the Banco de Crédito Hipotecario indicated that its situation was very difficult. It had suspended all its operations due to economic and monetary critical situation of the country (Banco de Crédito Hipotecario 1884).

30 Population data for 1870 suggest a similar figure (Table 2).
} 
information costs, merchant lenders may have found it efficient and less risky to allocate loans to merchants. Consistently, the evidence indicates that merchant borrowers accounted for an important portion of credit. In particular, merchants received 35 per cent of the volume of credit in 18601877 (Table 9).

Certainly, the fact that merchants received a large portion of credit cannot be interpreted as conclusive evidence in favour of the hypothesis that there were market imperfections in the private credit market of Lima. Another plausible explanation for the large participation of merchants as borrowers is that commerce was in need of more credit than other economic activities. If this was the case, then even in the absence of high transaction and information costs, merchants would have been important recipients of credit. I do not have enough information on the sectoral demand for credit to determine whether merchants required more credit than individuals from other sectors. However, information on the composition of the population suggests that merchants were not necessarily the main sector in demand for credit. In 1876, for example, census data indicate that there were only 6,000 merchants in the province in Lima ${ }^{31}$, and $>10,000$ persons were labourers or artisans. In addition, $>5,000$ persons worked in agriculture and livestock, and there were $>11,000$ service workers, around 5,200 state employees, and around 4,000 professionals ${ }^{32}$. I do not know whether most service workers, state employees or professionals required credit. However, it is plausible that artisans needed credit for their economic activities. Their participation as borrowers in the private credit market of Lima, however, was extremely limited. According to our records, only 2 per cent of the number of loans served artisans and labourers. There were twice as many artisans as merchants in 1876; however, artisans received around one-tenth of the number of loans received by merchants. Therefore, it does not seem plausible that merchants received a very high portion of credit exclusively because of differences in the demand for credit.

Furthermore, the evidence for financial transactions among nonmerchants seems to favour the hypothesis that there were transaction and information costs. In the presence of market asymmetries, one would expect non-merchant lenders to have largely lent funds to individuals with similar occupations. Consistently, out of the 104 loans granted by members of the Army in 1860-1877, forty-one of them were provided to other members of the Army (Table 10). Similarly, among the 141 loans made by landowners and agriculturists, forty of them were granted to other landowners and agriculturists. Overall, 27 per cent of all loans granted in 1860-1877 corresponded to lenders and borrowers with the same occupations ${ }^{33}$. Considering loans

\footnotetext{
31 These figures come from Ruiz (2001, p. 62).

32 Including health professionals, liberal-arts professionals and teachers.

33 Here I only consider loans with information about the occupations of lenders and borrowers.
} 
TABLE 9

DISTRIBUTION OF LOANS, ACCORDING TO THE OCCUPATION AND GENDER OF BORROWERS, 1860-77 (\%)

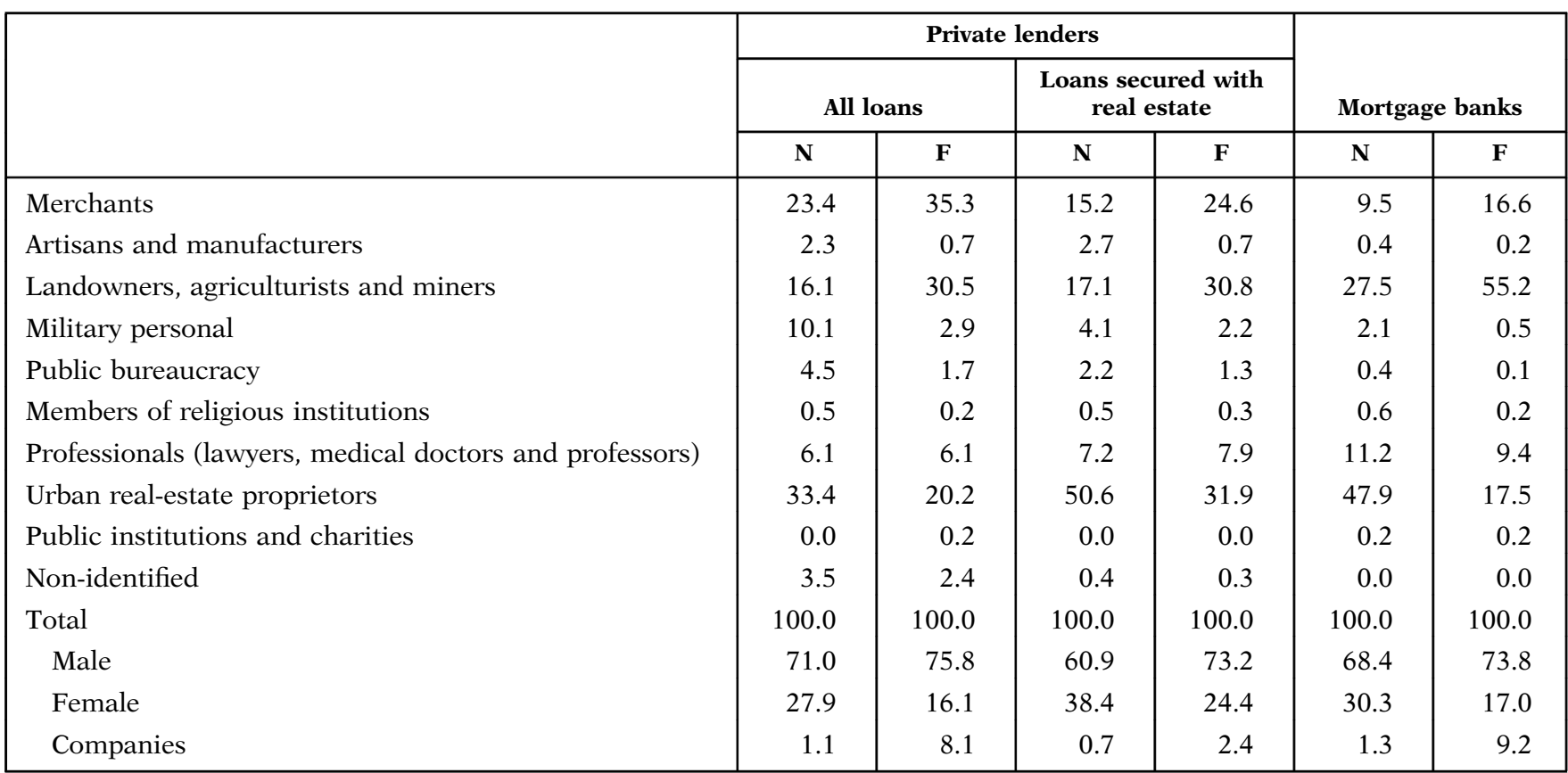

Notes: The table reports the percentages of the number of loans and the volume of credit. $\mathrm{N}$ is the number of contracts and $\mathrm{F}$ is the volume of credit. The information comes from the notaries of José de Selaya and Felipe Orellana. 
TABLE 10

NUMBER OF LOANS, ACCORDING TO THE OCCUPATIONS OF LENDERS AND BORROWERS, 1860-77

\begin{tabular}{|c|c|c|c|c|c|c|c|c|c|c|c|}
\hline Borrowerslenders & Merchants & $\begin{array}{l}\text { Artisans and } \\
\text { manufacturers }\end{array}$ & $\begin{array}{l}\text { Landowners } \\
\quad \text { and } \\
\text { agriculturists }\end{array}$ & $\begin{array}{l}\text { Military } \\
\text { personal }\end{array}$ & $\begin{array}{c}\text { Public } \\
\text { bureaucracy }\end{array}$ & $\begin{array}{l}\text { Members } \\
\text { of } \\
\text { religious } \\
\text { institutions }\end{array}$ & $\begin{array}{c}\text { Professionals } \\
\text { (lawyers, medical } \\
\text { doctors } \\
\text { and professors) }\end{array}$ & $\begin{array}{c}\text { Urban } \\
\text { real- } \\
\text { estate } \\
\text { proprietors }\end{array}$ & $\begin{array}{c}\text { Public } \\
\text { institutions } \\
\text { and charities }\end{array}$ & $\begin{array}{c}\text { Non- } \\
\text { identified }\end{array}$ & Total \\
\hline Merchants & 256 & 11 & 27 & 9 & 8 & 8 & 28 & 28 & 1 & 289 & 665 \\
\hline $\begin{array}{l}\text { Artisans and } \\
\text { manufacturers }\end{array}$ & 14 & 7 & 0 & 1 & 0 & 0 & 6 & 7 & 0 & 29 & 64 \\
\hline $\begin{array}{l}\text { Landowners and } \\
\text { agriculturists }\end{array}$ & 166 & 2 & 40 & 19 & 6 & 2 & 27 & 40 & 0 & 151 & 453 \\
\hline Miners & 2 & 0 & 1 & 1 & 0 & 0 & 0 & 1 & 0 & 0 & 5 \\
\hline Military personal & 160 & 3 & 5 & 41 & 9 & 2 & 3 & 10 & 0 & 54 & 287 \\
\hline Public bureaucracy & 74 & 1 & 4 & 4 & 3 & 0 & 5 & 13 & 0 & 23 & 127 \\
\hline $\begin{array}{l}\text { Members of religious } \\
\text { institutions }\end{array}$ & 2 & 0 & 1 & 1 & & 2 & 1 & 1 & 0 & 6 & 14 \\
\hline $\begin{array}{l}\text { Professionals } \\
\text { (lawyers, medical } \\
\text { doctors and } \\
\text { professors) }\end{array}$ & 55 & 3 & 6 & 5 & 5 & 3 & 13 & 20 & 0 & 64 & 174 \\
\hline $\begin{array}{l}\text { Urban real-estate } \\
\text { proprietors }\end{array}$ & 245 & 25 & 52 & 19 & 41 & 12 & 51 & 110 & 6 & 387 & 948 \\
\hline $\begin{array}{l}\text { Public institutions and } \\
\text { charities }\end{array}$ & 1 & 0 & 0 & 0 & 0 & 0 & 0 & 0 & 0 & 0 & 1 \\
\hline Non-identified & 30 & 2 & 5 & 4 & 5 & 3 & 7 & 6 & 0 & 37 & 99 \\
\hline Total & 1,005 & 54 & 141 & 104 & 77 & 32 & 141 & 236 & 7 & 1,040 & 2,837 \\
\hline
\end{tabular}

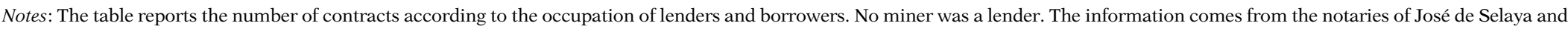
Felipe Orellana. 
where merchants did not participate as borrowers or lenders, around 34 per cent of the number of loans corresponded to individuals with the same occupations. Excluding urban real-estate proprietors, the percentage was 46 per cent.

On the other hand, transaction and information costs may be higher for interregional financial transactions than for local transactions. Lenders may face high information costs to know whether borrowers from other cities are good credit risks, and borrowers may face high transaction costs for finding lenders from other cities. To offset these costs, lenders can find it efficient to allocate their funds to borrowers from the same city.

In our sample of loans notarised in Lima, most borrowers and lenders lived in the province of Lima; only a minor proportion came from other provinces (Tables 5 and 11). Consistently with the hypothesis of high information costs, the evidence shows that in 1860-1877, out of loans for which there is complete information of the residences of lenders and borrowers, around 89 per cent of the contracts were transacted between lenders and borrowers from the same city, in particular Lima (Table 12). Limeños (individuals with a residence in Lima) in need of funding borrowed money from other limeños.

A similar picture is drawn from other primary sources, in particular, from notarial records from other regions in Peru. For instance, scattered evidence from notaries in Ica (a city 190 miles south of Lima) shows that lenders and borrowers were usually inhabitants of the city Ica and the nearby towns and haciendas. Also, data from notaries in Cañete (a city 90 miles south of Lima) show that most lenders and borrowers lived in this city or in nearby small towns and haciendas. This evidence shows that prior to the creation of mortgage banks the Peruvian credit market was highly regional.

Borrowing within families is another mechanism to cope with transaction and information costs in the absence of banks. To identify whether lenders and borrowers belonged to the same families, I relied on information from the loan contracts. I made the assumption that the lenders and borrowers belonged to the same family when they had the same last name, or when the contract indicated that the lenders and borrowers belonged to the same family. The evidence, however, shows that financial transactions within families only represented a very small proportion of loans. In 1860-1877, for example, only 1.5 per cent of the number of loans was transacted between members of the same family ${ }^{34}$.

Therefore, the evidence is consistent with the hypothesis that there were large market imperfections in the private credit market of Lima. The credit market was highly regional, and a substantial amount of funding occurred within the same business and professional circles.

34 One potential problem with this result is that lenders and borrowers may belong to the same family if they do not have the same last name, or even if the contract does not indicate that they are relatives. 
TABLE 11

DISTRIBUTION OF LOANS, BY RESIDENCE OF BORROWERS AND BY LOCATION OF GUARANTEE, 1860-77

\begin{tabular}{|l|r|r|r|r|r|r|}
\hline \multirow{2}{*}{} & \multicolumn{4}{|c|}{ Private lenders } & \multicolumn{2}{c|}{} \\
\cline { 2 - 5 } & \multicolumn{2}{|c|}{ All loans } & \multicolumn{2}{c|}{$\begin{array}{c}\text { Loans secured } \\
\text { with real estate }\end{array}$} & \multicolumn{2}{c|}{ Mortgage banks } \\
\cline { 2 - 5 } & $\mathbf{N}$ & $\mathbf{F}$ & $\mathbf{N}$ & $\mathbf{F}$ & $\mathbf{N}$ & $\mathbf{F}$ \\
\hline Residence of borrowers & & & & & & \\
Province of Lima & 89.3 & 84.8 & 75.6 & 81.5 & 80.1 & 67.1 \\
Other provinces of the & 1.8 & 3.3 & 0.8 & 1.2 & 1.7 & 1.8 \\
department of Lima & & & & & & \\
Callao & 2.3 & 1.4 & 1.7 & 0.8 & 7.6 & 3.3 \\
Northern coast & 1.4 & 4.6 & 0.8 & 1.0 & 7.4 & 25.5 \\
Southern coast & 1.6 & 2.6 & 0.9 & 1.9 & 3.0 & 2.3 \\
Highlands and jungle & 1.2 & 1.3 & 0.9 & 1.1 & 0.0 & 0.0 \\
Other countries & 0.2 & 1.3 & 0.1 & 0.1 & 0.0 & 0.0 \\
Non-identified & 2.1 & 0.8 & 19.2 & 12.4 & 0.2 & 0.0 \\
Location of collateral & & & & & & \\
Province of Lima & 61.1 & 52.4 & 81.2 & 67.8 & 56.4 & 33.5 \\
Other provinces of the & 2.6 & 4.7 & 3.4 & 7.2 & 5.5 & 13.3 \\
$\quad$ department of Lima & & & & & & \\
Callao & 3.3 & 2.3 & 5.0 & 3.5 & 15.0 & 6.0 \\
Northern coast & 2.1 & 6.8 & 3.2 & 8.4 & 10.6 & 40.2 \\
Southern coast & 2.3 & 6.6 & 3.4 & 7.0 & 10.4 & 5.7 \\
Highlands and jungle & 1.0 & 1.2 & 1.3 & 2.1 & 0.4 & 0.4 \\
Other countries & 0.2 & 0.1 & 0.2 & 0.1 & 0.0 & 0.0 \\
Non-identified & 27.6 & 25.8 & 2.3 & 4.0 & 1.7 & 0.8 \\
\hline
\end{tabular}

Notes: The table reports the percentages of contracts and volume of credit. $\mathrm{N}$ is the number of contracts, $\mathrm{F}$ is the amount of credit. The information comes from the notaries of José de Selaya and Felipe Orellana.

\section{DID BANKS BROADEN ACCESS TO CREDIT?}

Transaction theory suggests that as banks economise on transaction and information costs, they can contribute with the creation of an impersonal credit market and can broaden access to credit. Without banks, investors without personal and business linkages with merchants and other rich individuals may have difficulties to find funding. If banks coped with transaction and information costs better than private lenders, it is possible that 
TABLE 12

NUMBER OF LOANS, ACCORDING TO THE RESIDENCE OF LENDERS AND BORROWERS AND FAMILY TIES, 1860-77

\begin{tabular}{|c|c|c|}
\hline Description & $\begin{array}{l}\text { Number of } \\
\text { loans }\end{array}$ & $\%$ \\
\hline $\begin{array}{l}\text { Lenders and borrowers from the same department/ } \\
\text { province }\end{array}$ & 1,724 & 88.6 \\
\hline Province of Lima ${ }^{1}$ & 1,710 & 87.9 \\
\hline Other provinces in the department of Lima ${ }^{2}$ & 5 & 0.3 \\
\hline Department of Arequipa ${ }^{3}$ & 1 & 0.1 \\
\hline Department of La Libertad ${ }^{3}$ & 1 & 0.1 \\
\hline Department of Lambayeque ${ }^{3}$ & 2 & 0.1 \\
\hline Department of Ancash ${ }^{3}$ & 2 & 0.1 \\
\hline Department of Junin ${ }^{3}$ & 1 & 0.1 \\
\hline Department of Tacna ${ }^{3}$ & 1 & 0.1 \\
\hline Department of Apurimac ${ }^{3}$ & 1 & 0.1 \\
\hline $\begin{array}{l}\text { Lenders and borrowers in different departments/ } \\
\text { provinces }\end{array}$ & 222 & 11.4 \\
\hline Total $^{4}$ & 1,946 & 100.0 \\
\hline Lenders and borrowers in the same family & 42 & 1.5 \\
\hline Lenders and borrowers in different families & 2,795 & 98.5 \\
\hline Total $^{5}$ & 2,837 & 100.0 \\
\hline
\end{tabular}

Notes: Peru was politically divided into departments. Each department was divided into provinces. The information comes from the notaries of José de Selaya and Felipe Orellana.

${ }^{1}$ Lenders and borrowers lived in the province of Lima.

${ }^{2}$ Lenders and borrowers lived in the department of Lima but not in the province of Lima.

${ }^{3}$ Lenders and borrowers lived in the same department.

${ }^{4}$ Loans without missing information on the residences of borrowers and lenders.

${ }^{5}$ All loans.

the creation of banks facilitated access to credit for individuals without previous access to funding. Another plausible effect of the creation of banks, however, is that banks facilitate credit to the well connected. In this case, banks will cope with transaction and information costs better than private lenders but not to the extent of reaching individuals without personal or business connections; banks will just serve as intermediaries between savers and the business elite.

In the previous section, I reported evidence that supports the hypothesis that there were market imperfections in the private credit market. Did banks economise on transaction and information costs to the extent 
of broadening access to credit for people outside the commercial and business elite?

The evidence indicates that a substantial number of bank borrowers previously participated in the private credit market as borrowers, and even as lenders. Francisco García-Calderón, an important shareholder of the Banco de Crédito Hipotecario, indicated that many loans granted by this bank served to cancel mortgage loans from the first year of operations (García-Calderón 1868, p. 93). In other words, many of the bank's borrowers had already participated in the credit market. From our sample, in 1866-1873 around 30 per cent of the total value of bank credit served to repay previous loans to private lenders. Furthermore, scattered evidence shows that some bank borrowers that did not rely on bank loans to repay previous debts (which accounted for 70 per cent of the value of bank credit) had also received credit previously. Cipriano Dulanto, for example, borrowed 110,000 soles from the Banco de Crédito Hipotecario in 1870 and 1872 to invest in his haciendas Torre Blanca and Lauri in the province of Chancay ${ }^{35}$. Dulanto had already received funding from Juan del Busto in 1867 and $1868^{36}$. Fernando Palacios obtained four loans in 1871 and 1872 from the Banco Territorial Hipotecario for a total amount of 130,000 soles to invest in their fincas in Lima and a hacienda in $\mathrm{Ica}^{37}$. Palacios had already borrowed money from Nicolás de Piérola in 1862, and from Domingo Bello in $1865^{38}$. Palacios had also lent funds to Manuel Miranda in $1863^{39}$.

That a portion of bank borrowers had already received credit does not necessarily imply that the number of borrowers remained the same after the creation of banks. In fact, the creation of banks led to an expansion in the number of borrowers. For loans secured with real estate from the province of Lima, our estimates indicate that the number of borrowers increased after the creation of mortgage banks. In total, private lenders granted loans to $>200$ different borrowers in 1866 (Figure 2). Private lenders granted loans to 164 borrowers in 1871 and 187 in 1873 . Mortgage banks lent funds to sixtyone borrowers in 1871 and eighty-two individuals 2 years later. There was an increase in the total number of borrowers from 208 in 1866 to 258 in 1873 as mortgage banks started to operate ${ }^{40}$.

Nevertheless, in spite of the increase in the number of borrowers, the creation of banks did not generate a less concentrated allocation of credit (Figure 6). Prior to the creation of banks, the allocation of credit was already very concentrated. In 1865, for example, considering loans secured with real

\footnotetext{
35 AGN, Notary of José de Selaya, Protocolos 745 and 750.

36 AGN, Notary of Felipe Orellana, Protocolos 505 and 507.

37 AGN, Notary of Felipe Orellana, Protocolos 516 and 517.

38 AGN, Notary of José de Selaya, Protocolo 725, Notary of Francisco Palacios, Protocolo 566.

39 AGN, Notary of José de Selaya, Protocolo 728.

40 The increase in the number of borrowers was short-lived. In 1874 only sixteen borrowers had access to bank credit and in 1877 only five individuals borrowed money from the two banks.
} 
FIGURE 6

CONCENTRATION OF LOANS SECURED WITH REAL ESTATE FROM LIMA

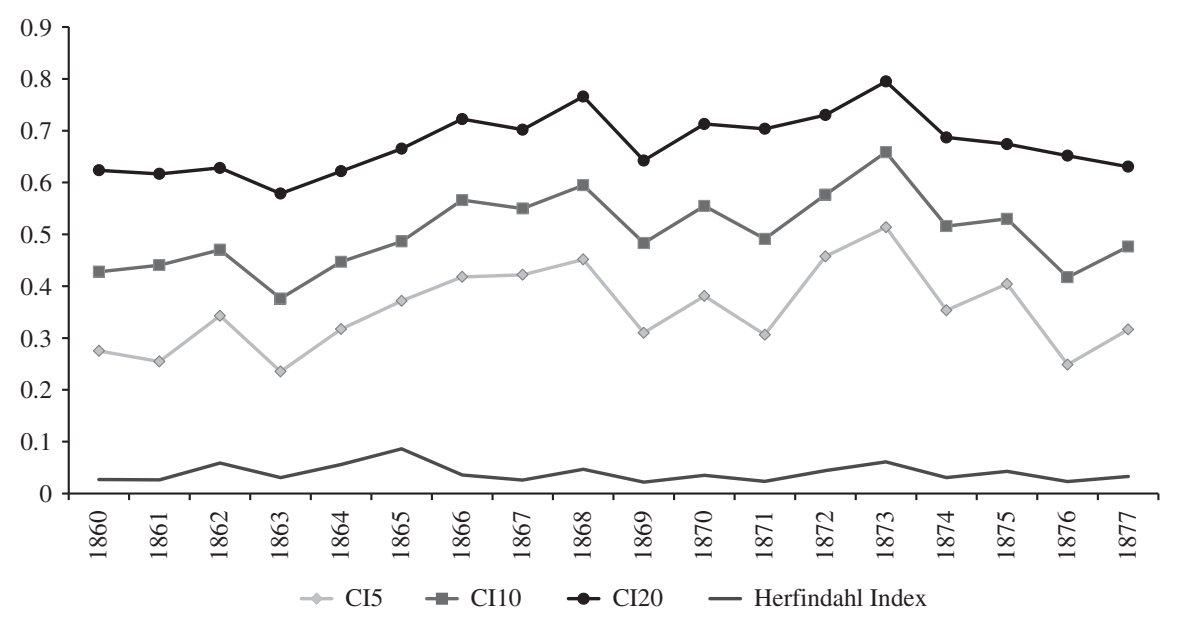

Notes: The figure depicts concentration indexes for the 5 per cent largest borrowers (CI5), the 10 per cent largest borrowers (CI10) and the 20 per cent largest borrowers (CI20), and the Herfindahl index for the entire sample of loans secured with real estate from Lima. CI5 is the proportion of credit granted to the 5 per cent largest borrowers, and CI10 is the proportion of credit granted to the 10 per cent largest borrowers, and CI20 is the proportion of credit granted to the 20 per cent largest borrowers.

estate from Lima, the largest 20 per cent of borrowers received around 67 per cent of all credit in $1865^{41}$. After the creation of banks, concentration did not decline. The participation of the largest 20 per cent of borrowers actually increased to 73 per cent in 1872 and 79 per cent in 1873. The Herfindahl index did not decline either after $1866^{42}$. Bank reports consistently suggest that banks did not lead to a less concentrated allocation of credit. Much of the bank credit served large sugar and cotton landlords. Sugar and cotton landlords were among the main beneficiaries of the two mortgage banks. A report by the Banco de Crédito Hipotecario indicates that this bank benefited sugar and cotton producers in 1870-1883 (Banco de Crédito Hipotecario 1883). Another report published in 1884 indicates that among the loans by the Banco Territorial Hipotecario, most loans granted by rural estates funded sugar and cotton production (Banco Territorial Hipotecario 1884).

41 In contrast, concentration increased on the supply side due to the important volume of credit granted by the mortgage banks.

42 Concentration slightly increased within private lenders' loans. However, in 1872-1873 (peak years for the value of credit by mortgage banks) concentration for the overall sample was greater than for private lenders, as indicated by the CI20 indexes. 
Therefore, the evidence shows that the creation of banks led to an increase in the number of borrowers. The creation of banks, however, did not lead to a less concentrated allocation of credit. Banks largely served the credit needs of large estate owners, especially hacendados in Lima and other coastal valleys.

\section{MORTGAGE BANKS AND REGIONAL ALLOCATION}

The fact that mortgage banks did not lead to a less concentrated allocation of credit cannot be interpreted as evidence that banks did not cope with market imperfections better than private lenders. For example, mortgage banks could have economised on transaction and information costs within the business elite of Peru, facilitating interregional transactions. This section shows that mortgage banks served as interregional intermediaries, receiving funds from Lima and other provinces (but mostly from Lima) to be invested all over the coast of Peru.

Mortgage banks received an important portion of their funding from the city of Lima. Among the main shareholders of Banco de Crédito Hipotecario ${ }^{43}$, most were merchants from Lima. Buenaventura Elguera, Juan Manuel Montes, José Vicente Oyague (and his brother), Pedro Denegri, Carlos Gonzales de Cándamo, Juan Mariano Goyeneche y Gamio, José Canevaro e Hijos, Antonio Joaquín Ramos and Sescau Valdeavellano y Cia were merchants from Lima. A few shareholders did not live in Lima, however. For instance, the commercial house Delgado Hermanos, Hijos y Cía, from the northern department of Lambayeque, was an important shareholder of the bank. Another shareholder was the Montero family, with haciendas in the province of Chancay. In the case of the Banco Territorial Hipotecario, merchants and proprietors were also the main shareholders ${ }^{44}$.

If the two mortgage banks economised on the process of collecting information about the creditworthiness of borrowers, one would expect banks to have allocated a relatively higher fraction of their loans (with respect to Lima's private lenders) to individuals living outside the province of Lima (non-limeños). Consistently, the evidence shows that mortgage banks allocated a larger portion of their loans to non-limeños than did private lenders. In the case of loans by private lenders, in 1860-1877 around 6 per cent of the value of loans secured with real estate went to non-limeños, and 12 per cent went to individuals without an identified residence. For mortgage banks, the importance of non-limeños as a destination of funding was greater (Table 11). Among loans by mortgage banks, around 33 per cent

43 Here I consider shareholders with forty or more shares.

44 It is certainly possible that individuals living in other departments owned mortgage bonds. Around 50 per cent of mortgage bonds, however, were owned by the mortgage banks themselves. 
of the value of loans in 1866-1877 served non-limeños, especially individuals living on the northern coast.

In addition, economic theory suggests that banks can economise on information costs about the characteristics of the loans' guarantees; banks may face scale economies on the process of obtaining information about the value of the collateral. If the two mortgage banks economised on such information, one would expect these banks to have secured a relatively higher fraction of their loans with estates located outside Lima than private lenders. Consistently, the evidence indicates that mortgage banks secured a higher fraction of their loans with estates located outside the province of Lima than did private lenders. In 1860-1877, 28 per cent of the value of credit by private lenders was secured with estates outside from Lima. For mortgage banks, the percentage was $>65$ per cent. Only 34 per cent of the total value of new loans by mortgage banks was secured with estates located in the province of Lima ${ }^{45}$. In addition, 13 per cent of the value of bank credit was secured with estates located in other provinces of the department of Lima, especially in the provinces of Chancay and Cañete, and 40 per cent was secured with estates on the northern coast. In the same direction, bank yearbooks indicate that a large number of loans were secured with estates on the northern coast, especially sugar and cotton estates (see Banco de Crédito Hipotecario 1883; Banco Territorial Hipotecario 1884).

Table 13 confirms that within the sample it was more likely that the collateral was located outside Lima among bank loans than among private lenders' loans. Columns 1-3 show the probit results for LIMA as dependent variable. The estimates in column 1 indicate that the probability of lending on collateral from Lima was 0.25 lower among bank loans than among private lenders' loans. Even controlling for the occupation and gender of the borrower, the type of collateral, and year fixed-effects, the effect of the dummy variable BANK is negative and highly significant.

Nevertheless, the integration of regional credit markets due to the appearance of mortgage banks did not reach the entire country and neither did bank credit; most credit was highly concentrated on the coast. Mortgage banks allocated practically no credit to the highlands or the jungle of Peru. Junin in the central highlands and Cuzco and Puno in the southern highlands, for example, received almost no credit from the two mortgage banks.

Therefore, consistent with transaction theory, the evidence indicates that mortgage banks facilitated the mobilisation of capital across regions. Although mortgage banks did not serve estate owners from the entire country, they served as intermediaries between limeños and non-limeños, channelling savings from Lima and other provinces (but mostly from Lima) to invest in real estate located in Lima and other coastal provinces.

45 Most loans by the two mortgage banks went to limeños; however, an important fraction of these loans were secured with estates located outside the province of Lima. 
TABLE 13

PROBIT AND ORDINARY LEAST SQUARES (OLS) ESTIMATES

\begin{tabular}{|c|c|c|c|c|c|c|c|c|c|c|c|}
\hline & \multicolumn{3}{|c|}{ Dependent variable: LIMA } & \multicolumn{4}{|c|}{ Dependent variable: LNSIZE } & \multicolumn{4}{|c|}{ Dependent variable: LNMATURITY } \\
\hline & 1 & 2 & 3 & 4 & 5 & 6 & 7 & 8 & 9 & 10 & 11 \\
\hline BANK & $\begin{array}{c}-0.25 \\
(0.02)^{* * *}\end{array}$ & $\begin{array}{c}-0.19 \\
(0.02)^{* * *}\end{array}$ & $\begin{array}{c}-0.17 \\
(0.03)^{* * *}\end{array}$ & $\begin{array}{c}1.44 \\
(0.07)^{* * *}\end{array}$ & $\begin{array}{c}1.25 \\
(0.07)^{* * *}\end{array}$ & $\begin{array}{c}1.27 \\
(0.08)^{* * * *}\end{array}$ & $\begin{array}{c}0.46 \\
(0.20)^{* *}\end{array}$ & $\begin{array}{c}2.69 \\
(0.04)^{* * * *}\end{array}$ & $\begin{array}{c}2.7 \\
(0.04)^{* * *}\end{array}$ & $\begin{array}{c}2.74 \\
(0.05)^{* * *}\end{array}$ & $\begin{array}{c}2.34 \\
(0.10)^{* * *}\end{array}$ \\
\hline $\mathrm{COM}$ & & $\begin{array}{c}-0.08 \\
(0.03)^{* * *}\end{array}$ & $\begin{array}{c}-0.08 \\
(0.03)^{* * * *}\end{array}$ & & $\begin{array}{c}0.59 \\
(0.08)^{* * * *}\end{array}$ & $\begin{array}{c}0.59 \\
(0.08)^{* * * *}\end{array}$ & $\begin{array}{c}0.84 \\
(0.27)^{* * * *}\end{array}$ & & $\begin{array}{c}0.02 \\
(0.05)\end{array}$ & $\begin{array}{c}0.03 \\
(0.05)\end{array}$ & $\begin{array}{l}-0.12 \\
(0.13)\end{array}$ \\
\hline FEM & & $\begin{array}{c}0.04 \\
(0.02)^{* * *}\end{array}$ & $\begin{array}{c}0.04 \\
(0.02)^{* k *}\end{array}$ & & $\begin{array}{c}-0.25 \\
(0.06)^{* k * k}\end{array}$ & $\begin{array}{c}-0.25 \\
(0.06)^{* * *}\end{array}$ & $\begin{array}{c}-0.32 \\
(0.15)^{* *}\end{array}$ & & $\begin{array}{c}0.06 \\
(0.03)\end{array}$ & $\begin{array}{c}0.06 \\
(0.03)\end{array}$ & $\begin{array}{l}-0.06 \\
(0.07)\end{array}$ \\
\hline URBAN & & $\begin{array}{c}0.53 \\
(0.03)^{* * *}\end{array}$ & $\begin{array}{c}0.53 \\
(0.03)^{* * *}\end{array}$ & & $\begin{array}{c}-1.04 \\
(0.08)^{* * *}\end{array}$ & $\begin{array}{c}-1.06 \\
(0.08)^{* * * *}\end{array}$ & $\begin{array}{c}-0.64 \\
(0.26)^{* * *}\end{array}$ & & $\begin{array}{l}-0.01 \\
(0.05)\end{array}$ & $\begin{array}{l}-0.01 \\
(0.05)\end{array}$ & $\begin{array}{c}0 \\
(0.13)\end{array}$ \\
\hline LIMA & & & & & $\begin{array}{l}-0.11 \\
(0.07)\end{array}$ & $\begin{array}{l}-0.11 \\
(0.07)\end{array}$ & & & $\begin{array}{c}0.04 \\
(0.04)\end{array}$ & $\begin{array}{c}0.05 \\
(0.04)\end{array}$ & \\
\hline Year fixed-effects & No & No & Yes & No & No & Yes & Yes & No & No & Yes & Yes \\
\hline$R^{2} /$ pseudo $R^{2}$ & 0.05 & 0.25 & 0.26 & 0.17 & 0.3 & 0.31 & 0.22 & 0.72 & 0.73 & 0.73 & 0.85 \\
\hline$R^{2}$ adjusted & & & & 0.17 & 0.30 & 0.31 & 0.15 & 0.72 & 0.73 & 0.73 & 0.83 \\
\hline$N$ & 2,144 & 2,138 & 2,138 & 2,178 & 2,128 & 2,128 & 264 & 2,047 & 2,005 & 2,005 & 261 \\
\hline
\end{tabular}

Notes: The table reports probit marginal effects for LIMA as dependent variable, and OLS estimates for LNSIZE and LNMATURITY as dependent variables. Standard errors are in parentheses. Information comes from the notaries of José de Selaya and Felipe Orellana for 1860-77. LIMA is a dummy variable that adopts a value of 1 if the collateral was located in the province of Lima (0 otherwise), LNSIZE is the natural log of the size of loans (in silver soles), LNMATURITY is the natural log of the maturity of loans (in years), BANK is a dummy variable ( 1 if the lender is a mortgage bank, 0 if the lender is a private lender), COM is a dummy variable that adopts a value of 1 if the borrower is a merchant ( 0 otherwise), FEM is a dummy variable that adopts a value of 1 if the borrower is female ( 0 otherwise) and URBAN is a dummy variable that adopts a value of 1 if the collateral is an urban estate ( 0 if it is rural). Columns 1-6 and 8-10 include all loans. Columns 7 and 11 only include loans to borrowers that borrowed from private lenders and mortgage banks in 1860-77. The data set corresponds to all loans secured with real estate and notarised by José de Selaya and Felipe Orellana. Significance levels: $* * * 1 \%, * * 5 \%, * 10 \%$. 


\section{ACCESS TO LONG-TERM CREDIT}

Banks may have contributed to the development of productive sectors in need of long-term capital. In theory, without financial intermediaries, transaction costs make it costly for borrowers to access large loans or loans with long maturity. Borrowers in need of large loans would have to know savers with abundant capital. In addition, even if borrowers have personal connections with wealthy lenders, making large loans may be too risky for an individual lender. Alternatively, matching long-term investors with long-term savers is probably very costly without financial intermediation.

The evidence for Peru shows that the creation of banks had an impact on the size of loans. Mortgage banks made much larger mortgage loans than private lenders. Consider loans secured with real estate from the province of Lima (Table 14). Private lenders made loans with an average size of 3,275 soles in 1860-1865 and 4,578 soles in 1866-1877. Mortgage banks made loans with an average of $>14,000$ soles in 1866-1877. For private lenders and mortgage banks, loans secured with rural estates were larger than those secured with urban estates. However, considering loans secured with urban estates or with rural estates, mortgage banks always made larger loans.

Table 13 confirms that banks provided larger loans than private lenders. Columns 4-7 show the ordinary least squares (OLS) results for LNSIZE as dependent variable. The estimates clearly indicate that mortgage banks granted larger loans than private lenders. Even controlling for the occupation and gender of the borrower, the type of collateral, and year fixed-effects, the effect of the dummy variable BANK is positive and highly significant.

In addition, mortgage banks made loans with longer maturities than private lenders. According to all contracts, the two mortgage banks always made loans for 20 years. In contrast, the average maturity of loans granted by private lenders and secured with real estate from the province of Lima was around 1.8 years in 1866-1877. Among urban loans, the average maturity was 1.8 years and among rural loans the figure was 1.9 years. The duration of loans by private lenders was short for investment in some productive sectors, especially agriculture. Francisco García-Calderón, in fact, argued that prior to the creation of mortgage banks the situation of agriculture was precarious due to the lack of long-term credit (García-Calderón 1868, pp. 11-12).

Table 13 confirms that mortgage banks provided loans with longer maturities than private lenders and commercial banks. Columns 8-11 report the OLS results for LNMATURITY as dependent variable. The estimates clearly indicate that banks granted far longer loans than private lenders. Even controlling for the occupation and gender of the borrower, as well as for the type of collateral and year fixed-effects, the effect of the dummy variable BANK on LNMATURITY is positive and highly significant. 
TABLE 14

LOAN SIZES AND MATURITY

\begin{tabular}{|c|c|c|}
\hline & $\begin{array}{c}\text { Loan sizes } \\
\text { (current silver soles) }\end{array}$ & $\begin{array}{c}\text { Maturity } \\
\text { (years) }\end{array}$ \\
\hline $\begin{array}{c}\text { Private lenders } \\
1860-65\end{array}$ & \\
Total & 3,275 & 1.9 \\
Urban & 3,057 & 1.9 \\
Rural & 5,811 & 1.8 \\
$1866-77$ & 4,578 & \\
Total & 4,314 & 1.8 \\
Urban & 8,772 & 1.8 \\
Rural & & 1.9 \\
Mortgage & & \\
banks & 14,060 & 20.0 \\
Total & 12,459 & 20.0 \\
Urban & 27,141 & \\
Rural & & \\
\hline
\end{tabular}

Notes: The table reports the average of loan sizes and maturity for loans secured with real estate from the province of Lima. The information on mortgage banks corresponds to 1866-77. The information comes from the notaries of José de Selaya and Felipe Orellana.

Transaction costs are not the only plausible explanation for the differences in loan sizes and maturities between private lenders and mortgage banks. Alternatively, it might be argued that market segmentation can also explain such differences; private lenders may have served clients who demanded small short-term loans and mortgage banks may have served clients who demanded large long-term loans. I cannot argue that there was no market segmentation between banks and private lenders. However, market segmentation could not fully explain the differences in loan sizes and maturity levels; analysing the sample of borrowers who obtained loans from mortgage banks and from private lenders (columns 7 and 11 in Table 13), I find that mortgage banks also made larger loans than private lenders, and with a longer maturities.

Therefore, as banks coped with transaction and information costs better than private lenders, banks provided larger loans to real-estate owners. In addition, mortgage banks were able to match long-term savers and long-term investors better than private lenders. These better loan conditions may have constituted a significant incentive for borrowers, especially large estate owners, to rely on mortgage banks as a source of long-term credit. 


\section{CONCLUSIONS}

In the absence of mortgage banks, private lenders from Lima channelled funds to several borrowers and with a variety of conditions. Some loans were for only a few months; others were for some years. Some loans were for only a few hundred soles; others for several thousand soles. Some loans were associated with no interest; others involved interest rates as high as 2 per cent or 3 per cent per month. Some loans were secured with houses and haciendas; others were secured with the borrowers' salaries, their inventories or constituted the traditional general mortgages.

As transaction theory establishes, however, the allocation of loans in the pre-banking credit market largely depended on personal connections. To obtain funds, borrowers had to recur to their neighbours and even to their colleagues. The evidence shows that the vast majority of real-estate loans in the pre-banking market of Lima was made by limeños to limeños and was secured with estates from Lima. Interregional financial transactions were extremely rare.

Mortgage banks, created in Peru from 1866, economised on transaction and information costs and channelled funds to borrowers from several cities and valleys, not only borrowers from Lima. A large fraction of credit went to landowners in the coastal valleys, in particular sugar and cotton producers. Whereas banks served borrowers from several cities, private lenders from Lima continued to allocate their funds to borrowers from Lima. Mortgage banks also offered loans in better conditions than private lenders. In particular, bank loans were larger and with a longer duration, which suggests that banks economised on transaction costs. In private credit markets, borrowers in need of major funding had to look for very wealthy lenders. Also, long-term investors had to find long-term savers willing to facilitate funds for several years. Transaction costs made large long-term loans hard to obtain. In contrast, mortgage banks made loans in large sizes and with maturities of 20 years.

However, consistently with the evidence for other countries ${ }^{46}$, the evidence for Peru indicates that early banks did not broaden access to credit. Banks economised on transaction and information costs, but not to the extent of broadening access to credit for individuals without previous access to credit. Most credit by mortgage banks went to large estate owners from the coast. Banks served as interregional financial intermediaries, facilitating access to long-term credit for urban proprietors from Lima and sugar and cotton hacendados from the coast.

The fact that banks did not broaden access to credit indeed deserves further research. It is possible that banks did not open up access to credit simply because they operated for just a few years. Mortgage banks started to operate in 1866; 13 years later bank credit was practically non-existent.

\footnotetext{
${ }^{46}$ See, for example, Wang (2008) for the United States and Levy (2012) for Mexico.
} 
If mortgage banks had continued operating for longer, it is possible that they would have served many more clients, perhaps clients without previous access to credit. It is also possible, however, that structural factors did not allow mortgage banks to serve more people. Deficiencies in the definition of property rights, for example, may have limited the extent of banking operations. At this stage of research, it is not possible to identify the reasons for the limited action of banks. Further research needs to be conducted ${ }^{47}$.

\section{REFERENCES}

Bagenot, W. (1873): Lombard Street: A Description of the Money Market. New York: Scribner, Armstrong \& Co.

Banco De Crédito Hipotecario. (1869): Memoria Presentada a Nombre del Consejo de Directores por el Gerente del Banco de Crédito Hipotecario, 1868. Lima: Imprenta y Litografía de E. Prugue.

Banco De Crédito Hipotecario. (1876): Memoria del Banco de Crédito Hipotecario correspondiente al año 1875 Presentada a los Accionistas en Junta General de febrero de 1876. Lima: Imprenta del Universo de Carlos Prince.

Banco De Crédito Hipotecario. (1883): Respuesta que da el Banco de Crédito Hipotecario al Folleto Publicado por el Comité de sus Deudores. Lima: Imprenta del Teatro.

Banco De Crédito Hipotecario. (1884): Memoria del Banco de Crédito Hipotecario Correspondiente al año de 1883 Presentada a los Accionistas en Junta General de febrero de 1884. Lima: Imprenta del Teatro.

Banco Territorial Hipotecario. (1870): Estatutos del Banco Territorial Hipotecario Autorizado por la ley de 4 de Febrero de 1869 y por su Supremo decreto de 31 de enero de 1866. Lima: Imprenta de El Nacional.

Banco Territorial Hipotecario. (1884): Memoria presentada a la Junta General de Accionistas por el año vencido en 31 de diciembre de 1884. Lima: Imprenta de la Merced, Peter Bacigalupi y Ca.

Benston, G., and Smith, C. W. (1976): «A Transaction Cost Approach to the Theory of Financial Intermediation». Journal of Finance 31, pp. 215-231.

Beveridge, A. (1985): «Local Lending Practice: Borrowers in a Small Northeastern Industrial City, 1832-1915». Journal of Economic History 45 (2, The Tasks of Economic History), pp. 393-403.

Bonilla, H. (1974): Guano y burguesía en el Perú, Perú Problema 11. Lima: Instituto de Estudios Peruanos.

BRYANT, J. (1980): «A Model of Reserves, Bank Runs and Deposit Insurance». Journal of Banking and Finance 43, pp. 749-761.

Camprubí, C. (1957): Historia de los bancos en el Perú: 1860-1879. Lima: Lumen.

Diamond, D. (1984): «Financial Intermediation and Delegated Monitoring». Review of Economic Studies 51, pp. 393-414.

Diamond, D., and Dybvig, P. (1983): «Bank Runs, Deposit Insurance and Liquidity». Journal of Political Economy 91, pp. 401-419.

47 Further research on insider lending also needs to be carried out. From our data set, we can only argue that most borrowers did not share the same last name with the members of the Board of Directors of the two mortgage banks. However, we recognise that identifying family relationships by last name underestimates the extent of insider lending. 
Engelsen, J. (1978): «Social Aspects of Agricultural Expansion in Coastal Peru», UCLA, Los Angeles, PhD dissertation in History.

Fuentes, M. (1860): Guía Histórico-Descriptiva, Administrativa, Judicial y de Domicilio de Lima. Lima: Librería Central.

Fuentes, M. (1863): Guía de Domicilio de Lima para el año de 1864. Lima: Imprenta del Autor.

Gallagher, J., and Espinoza, J. (1885): «Exposición de los Bancos Hipotecarios», Lima: Imprenta del Teatro.

García-Calderón, F. (1868): Estudios sobre el Banco de Crédito Hipotecario y las Leyes de Hipotecas. Lima: Imprenta dirigida por José M. Noriega.

García-Calderón, F. (1879): Diccionario de la Legislación Peruana. Lima: Fracisco García Calderón.

Gootenberg, P. (1990): "Carneros y Chuño: Price Levels in Nineteenth-Century Peru». Hispanic American Historical Review 70 (1), pp. 1-56.

HABER, S. (1991): "Industrial Concentration and the Capital Markets: A Comparative Study of Brazil, Mexico and the United States, 1830-1930». The Journal of Economic History 51 (3), pp. 559-580.

HaBER, S., and MAURER, N. (2002): «Institutional Change and Economic Growth: Banks, Financial Markets and Mexican Industrialization, 1878-1913», in J. Bortz, and S. Haber (eds), The Mexican Economy, 1870-1930. Stanford, CA: Stanford University Press, pp. 23-49.

Hanley, A. (2005): Native Capital. Financial Institutions and Economic Development in Sao Paulo, Brazil, 1850-1920. Stanford, CA: Stanford University Press.

Hicks, J. (1969): A Theory of Economic History. Oxford: Clarendon Press.

Hoffman, P.; Postel-Vinay, G., and Rosenthal, J.-L. (2000): Priceless Markets: The Political Economy of Credit in Paris, 1660-1870. Chicago, IL: University of Chicago Press.

Hoffman, P.; Postel-Vinay, G., and Rosenthal, J.-L. (2015): «Entry, Information and Financial Development: A Century of Competition Between French Banks and Notaries». Explorations in Economic History 55, pp. 39-57.

Hunt, S. (2010): La formación de la economía peruana. Distribución y crecimiento en la historia del Perú y América Latina. Lima: PUCP, BCRP, IEP.

Lamoreaux, N. (1986): «Banks, Kinship, and Economic Development: The New England Case». The Journal of Economic History 46 (3), pp. 647-667.

Leland, H. E., and Pyle, D. H. (1977): «Informational Asymmetries, Financial Structure and Financial Intermediation». The Journal of Finance 32, pp. 371-387.

Lemale, C. (1876): Almanaque del Comercio de Lima 1876. Lima: Imprenta del Estado.

Levy, J. (2012): The Making of a Market. Credit, Henequen and Notaries in Yucatan, 1850-1900. University Park, PA: The Pennsylvania State University Press.

Mcevoy, C. (2004): La experiencia burguesa en el Perú (1840-1940). Madrid: Iberoamericana.

Meiggs, E. (1871): Los Ferrocarriles del Perú. Colección de Leyes, Decretos, Contratos y demás Documentos Relativos a los Ferrocarriles del Perú. Lima: Imprenta del Estado.

Mitchell, B. R. (1993): International Historical Statistics. The Americas, 1750-1988. New York: Stockton Press.

Paz-Soldán, C. (1887): Bancos Hipotecarios. Estudio sobre su Organización y Operaciones en el Perú. Lima: Imprenta Liberal de F. Masías y Ca.

QuinN, S. (2001): «The Glorious Revolution's Effect on English Private Finance: A Microhistory, 1680-1705». Journal of Economic History 61 (3), pp. 593-615.

Quiroz, A. (1993): Domestic and Foreign Finance in Modern Peru, 1850-1950. Pittsburgh, PA: University of Pittsburgh Press. 
Redish, A. (2003): «The Mortgage Market in Upper Canada: Window on a Pioneer Economy», in S. Engerman, P. Hoffman, J.-L. Rosenthal, and K. Sokoloff (eds), Finance, Intermediaries, and Economic Development. Cambridge: Cambridge University Press, pp. 111-131.

Ruiz, A. (2001): La multitud, las subsistencias y el trabajo. Lima, 1890-1920. Lima: PUCP. Schumpeter, J. (1934): The Theory of Economic Development: An Inquiry Into Profits, Capital, Credit, Interest and the Business Cycle. Oxford: Oxford University Press.

SEminario, B. (2015): El desarrollo de la economía peruana en la Era Moderna. Lima: Universidad del Pacífico.

SuÁrez, M. (2001): Desafíos transatlánticos: Mercaderes, banqueros y el estado en el Perú Virreynal, 1600-1700. Lima: Instituto Riva Agüero-PUCP.

Triner, G. (2000): Banking and Economic Development: Brazil, 1889-1930. New York: Palgrave.

WANG, T.-C. (2008): «Banks, Credit Markets and Early American Development: A Case Study of Entry and Competition», in, The Journal of Economic History 68 (2), pp. 438-461.

Zegarra, L. F. (2006): Institutions, Economic Development and Early Banking in Latin America, 1850-1930. UCLA PhD Dissertation in Economics. Los Angeles, CA: UCLA.

Zegarra, L. F. (2013): «Free Banking and Financial Stability in Peru». Quarterly Journal of Austrian Economics 16 (2), pp. 187-226.

Zegarra, L. F. (2014a): «Women and Credit in Peru During the Guano Era. Was There Gender Discrimination in the Mortgage Credit Market of Peru?». Revista de Historia Económica - Journal of Iberian and Latin American Economic History 32 (1), pp. 151-185.

Zegarra, L. F. (2014b): «Bank Laws, Economic Growth and Early Banking in Latin America: 1840-1920», in, Explorations in Economic History 53 (3), pp. 101-119.

Zegarra, L. F. (2015): «Political Instability, Institutions and Mortgage Credit in Peru, 1830-65». CENTRUM Católica Working paper, Lima. 